\title{
Trust and Institutions: A Multilevel Analysis
}

\author{
Lanlan Wang and Peter Gordon \\ University of Southern California
}

\begin{abstract}
In this study, we argue that levels of trust are shaped by formal and informal institutions. We discuss statistical test results that support this case. These utilize World Value Survey results and related data sources to examine in what way institutions or contextual factors affect individual trust levels. This investigation is the first, to our knowledge, to take into account micro-unit and macro-unit hierarchical structures and analyze the nature of context effects by using multilevel regression approach.
\end{abstract}

\section{Introduction}

Trust is essential to economic and social interactions. It can be defined as confident reliance evolved in the division of labor and cooperation processes. In primitive societies, people relied on a small band of fellows for survival. Today we voluntarily engage in numerous interactions to get specialized services from people and organizations whom we scarcely know, but in whose credibility we have faith. Why do we, for example, risk our hard-earned money to prepay someone whom we never met for all sorts of items purchased over the internet? We desire exchange and we expect that there are rules and norms that go with these transactions that constrain opportunistic temptations and punish the exchange partners who fail to deliver goods or services in good faith. The sense of security and confident reliance that we have in these transactions is thus built upon 
formal and informal "rules of the game" to punish the defectors for breaches of contracts.

In this sense, institutions are the very foundations of trust that individual agents seek.

However, different views of the causal relationship between institution and trust have been proposed. Uslaner has claimed that "(t)rust leads to better institutions-not the other way around" ${ }^{\prime 1}$ based on the moral foundations of trust as he understood them. In his view, trust is "a general outlook on human nature and mostly does not depend upon personal experiences or upon the assumption that others are trustworthy" (Uslaner ${ }^{2}$ 2002, p.17, Italic origin). Fukuyama also argued that trust is a causal factor that prompts economic performance in his book, Trust. Aside from any methodological concerns ${ }^{3}$ over these studies, we would think that whether trust could be taken as a causal factor can boil down to basically a definitional issue.

The concept of trust could be understood from two aspects: first, like sympathy, conscience, selfishness, etc., trust is one of the basic human natures which do not involve moral-immoral judgments. From this human nature point of view, trust is everlasting but

\footnotetext{
${ }^{1}$ Uslaner, Eric M. (2004), Trust, Democracy, and Governance: Can Government Policies Influence Generalized Trust? in Dietlind Stolle and Marc Hooghe, eds., Generating Social Capital (Palgrave, 2004), http://www.bsos.umd.edu/gvpt/uslaner/generating5uslaner.doc.

${ }^{2}$ Uslaner, Eric M. (2002), The Moral Foundations of Trust, Cambridge University Press.

${ }^{3}$ In a book review by Charles Wolf, he pointed out that "in an exposition that repeatedly talks about degrees of trust, the extent of sociability, and the expansion or erosion of social capital, one would like to see some serious attention devoted to how to measure and reify these concepts. This is not an issue of the difference between the "touchy-feely" thinkers and the "quantoids," as one of my students has recently written. It is simply a requisite of serious analysis...Incidentally, with such a metric or metrics to concretize the concepts that Fukuyama is elaborating, it would be entirely possible to include them in economic models to test empirically the hypotheses he advances...Were that to happen, I would not expect them to survive the test. For the central argument of the book does not stand up to careful scrutiny" (http://www.highbeam.com/doc/1G1-17426436.html); In a cross-section empirical test, La Porta et al. (1997) claimed that they found "a striking confirmation of" the causal function of the trust factor in organization performance test, by using simple OLS method. This method alone cannot be used for causality analysis.
} 
difficult to measure and to compare different individuals across different times and place, even by using up-to-date technologies. Second, trust as revealed in our daily lives or measured by survey data is an "outlook of human nature" shaped and channeled ${ }^{4}$ by the institutional environment where we reside. This outlook of human nature does depend upon personal experiences. Or more specifically, trust depends on individual perceptions of the probability of being cheated in transactions that they experienced in. It varies over time, space or type of transactions, etc. Based on this understanding of the "trust" concept, we would argue that the moral foundations of trust that Uslaner claimed is only concerned with human nature, which is not captured by the data he used in his studies. In other words, his empirical data and the concept of trust in his studies denote different things that can hardly support his logic. In this study, trust only indicates the degree of trust or observed trust as revealed through individual behavior or perception ${ }^{5}$.

This study also argues that it is only institutions ${ }^{6}$ that have a causal effect on trust, not the other way around. Institutions, either formal or informal ones, defined as "rules of the game”, evolve to delineate boundaries of rights. To affect institutions requires socioeconomic activities that can adjust or generate incentives to adjust boundaries of rights. Trust itself is only concerned with the probability of taking responsibilities that an

\footnotetext{
${ }^{4}$ Beito, D. T., P. Gordon, A. Tabarrok (2002), Voluntary City, Michigan: The University of Michigan Press, p. 3.

${ }^{5}$ Some studies analyzed the component of trust. For example, in the paper by Glaeser et al (2000), trust was classified as "trusting" and "trustworthiness". "Trusting” is determined by individual's "specific instances of past trusting behaviors". And "trustworthiness" is defined by whether individual trusts others (Glaeser et al., p. 40). Both components, we think, depend upon personal experiences and knowledge, which is what we concerned in this study.

6 "Institution" includes formal and informal institution. As for informal institution, we might need to pay more attention to the difference between the two concepts: informal institution and trust. Some studies argued that trust could be substitute for formal institution (for example, Beugelsdijk and von Schaik (2001)). We would think that it is not trust, but rather the informal institutions which promote trust, that could substitute some formal institutions.
} 
individual would think that partner(s) should take voluntarily. Slave owners would trust slaves as long as the expected probabilities that the slave voluntarily did what the slave owner thought he should do were high, regardless of the fact that rights between these two agents had been immorally ${ }^{7}$ distributed. It is true that rights would shape responsibilities. But the incentives to readjust the rights for better performance come from cost-benefit considerations, more so than from trust. This investigation will follow this causality logic to analyze how and to what degree institutions, including formal and informal institutions, affect trust -- after controlling other relevant socioeconomic factors. Taking the fact that institutions have been widely regarded as a vague concept, trust might be one way to understand the quality of institutions as it is a mental picture or mental reflection of them.

\section{Literature Review}

In recent years, better data sources and techniques have made it possible to empirically analyze individual's perceptions and relate them to institutional factors. For these empirical studies of the trust issue, they could be classified into two types: one is based on individual-level data; another one is based on aggregated national-level data ${ }^{8}$.

For individual level study, Glaeser et al. used General Social Survey data and probit or OLS models to analyze trust in United States. They found that trust “is much lower for later cohorts”, but “much higher among richer and well-educated individuals”. They also report that “(m)en are slightly more trusting”. Higher levels of trust are associated with

\footnotetext{
${ }^{7}$ Moral argument is not preferred in this paper. Unfortunately this is the best word I could think of at this moment.

${ }^{8}$ Putnam's study is not included in this classification.
} 
married persons and members of "more educated (or wealthier) religious denominations", for instance, Methodist, Lutheran, Presbyterian, and Episcopalian religions. "City size has a slightly negative effect on amount of trust” (Glaeser et al ${ }^{9}, 2000$, p. 816, 818) ${ }^{10}$.

Individual-level studies by Guiso et al ${ }^{11}$ used World Value Survey data to analyze trust. They confirmed that some of the findings in the paper by Glaeser et al. could be generalized to a larger area, which included 66 countries. By controlling country fixed effects, they found that individual health, age, social status, income level, and religious belief showed positive and significant relationships with the trust. But different religions have different effects on trust. Religious belief, for example, in Protestant, Hindu, Catholic, and Muslim cultures tends to be positively and significantly related with the trust (Guiso et al., 2003, p. 256, Table 4). And “(p)articipation in religious services ${ }^{12}$ increases trust only among Christians. The effect is zero or even negative for other denominations. Within the Christian family, the effect is stronger for Protestants than for Catholics” (p. 228).

However, the individual-level studies referred to above only considered individual socioeconomic characteristics. To take national characteristics into consideration, previous empirical studies usually aggregated individual-level data to the national level.

\footnotetext{
${ }^{9}$ Edward L. Glaeser; David I. Laibson; Jose A. Scheinkman; Christine L. Soutter (2000), Measuring Trust, The Quarterly Journal of Economics, Vol. 115, No. 3, pp. 811-846

${ }^{10}$ La Porta, R., F. Lopez-de-Silanes, A. Shleifer, and R. Vishny (1997), Trust in Large Organizations, American Economic Review Papers and Proceedings, Vol. 87, No. 2, pp. 333-338.

${ }^{11}$ Guiso, Luigi, Paola Sapienza and Luigi Zingales (2003), People's Opium? Religion and Economic Attitudes, Journal of Monetary Economics, Vol. 50, No. 1, pp. 225-82.

Guiso, Luigi, Paola Sapienza and Luigi Zingales (2006), Does Culture Affect Economic Outcomes? Journal of Economic Perspectives, Vol. 20, No. 2, pp. 23-48

12 "Participation to religious services" is different from "religious belief" for World Value Survey data.
} 
For example, Knack and Keefer (1997) ${ }^{13}$ aggregate the World Value Survey data to 29 market economies and found that "trust and civic norms are stronger in nations with higher and more equal incomes, with institutions that restrain predatory actions of chief executives, and with better-educated and ethnically homogeneous populations” (Knack and Keefer 1997, p. 1251). In another paper by Zak and Knack ${ }^{14}$ (2001), they include 41 countries and find that the relationship between trust and growth "is far more robust to change in the specification or time period than in Knack and Keefer (1997). They also demonstrated that "institutions affect growth via their impact on trust" (p. 297). Their findings confirm that "trust ${ }^{15}$ is higher in more ethnically, socially, and economically homogenous societies, and where legal and social mechanisms for constraining opportunism are better developed, with high-trust societies exhibiting higher rates of investment and growth” (p. 298). In another country-level study done by La Porta et al., they conduct OLS estimations using World Value Survey data and claim a "striking confirmation” that support Putnam ${ }^{16}$ (1993) and Fukuyama’s theories. Namely, they observe that trust had a positive causal effect on judicial efficiency, anticorruption, bureaucratic quality, tax compliance, participation in civic activities, and share of large firms. This finding is problematic at least from a methodological point of view as OLS regressions could not be used to test causal relationships by themselves. Beugelsdijk and

\footnotetext{
${ }^{13}$ Knack, S., and P. Keefer (1997), Does Social Capital Have an Economy Payoff ? A Cross-Country Investigation, Quarterly Journal of Economics, Vol. 112, No. 4, pp. 1251-1288.

${ }^{14}$ Zak, Paul J and Stephen Knack (2001), Trust and Growth, The Economic Journal, 111 (April), p. 295321.

${ }^{15}$ More specifically, GDP per capita (1985) does not show consistent and robust effect on trust; "schooling" tends to have a positive but not robust impact on trust; "property rights index" is positively and significantly related with trust; And Gini income inequality, Gini land inequality, corruption and ethnic homogeneity have negative and significant effect on trust (Table 2, page 313). As for religion, they found that percent of Muslim, Catholic would negatively and significantly affect trust. Percent of Orthodox doesn't show significant impact on trust (Table 1, p. 308).

${ }^{16}$ Putnam, R.,, Leonardi, R., and Nanetti, R.Y (1993). Making democracy work. Princeton, New Jersey: Princeton University Press.
} 
Schaik $^{17}$ (2001) aggregated World Value Survey data to 54 European regions and presented evidence that “Fukuyama’s (1995) argument on trust does not hold and that Putnam’s (1993) thesis on group membership in Italian regions can be generalized” (p. 1). Tabellini ${ }^{18}$ (2005) also uses European regions as the unit of analysis and "documents that both GDP per capita and growth are higher in those regions that exhibit higher levels of 'good' cultural values like trust, beliefs in individual effort, generalized morality, and low obedience”. His analysis follows the same logic as in a paper by Zak and Knack (2001) and supports the idea that "institutions affect growth via their impact on trust" (Zak and Knack 2001, p. 297). A recent study by Berggren and Jordahl ${ }^{19}$ (2006) used newly released World Value Survey data and included more countries to analyze causal relationships between trust and economic institutions. The findings confirm their hypothesis that "the stronger the rule of law and the protection of property rights, the higher degree of generalized trust, all else held constant” (p. 145). And the share of the population belonging to a hierarchical religion (Catholic, Muslim, and Orthodox religions) used in their analysis shows negative relationships with trust.

As explained in the previous section, the causal relationship goes from institutions to trust; the causality issue and how trust would affect economic outcomes would not be the emphasis of this paper. Rather, we pay attention to analyzing to what degree institutions, including formal and informal institutions, affect trust levels, as a way to understand

\footnotetext{
${ }^{17}$ Beugelsdijk, S. and T. von Schaik (2001), Social Capital and Regional Economic Growth, CentER Discussion Paper, December. Religion is not considered in this paper.

${ }^{18}$ Tabellini, Guido (2005), Culture and institutions: economic development in the regions of Europe, working paper

${ }^{19}$ Berggren, N., H. Jordahl (2006), Free to Trust: Economic Freedom and Social Capital, Kyklos, Vol. 59, No. 2, pp. 141-169.
} 
institutions. The main problem with country-level studies by aggregating individual-level data is that they throw away all the within-country information which might contribute a large proportion of total variation (Raudenbush, Bryk ${ }^{20}$, 2002). As a consequence, relationships between aggregated variables could be very different from the relationships between the non-aggregated variables; interpretations could be distorted. On the other hand, the studies that only used individual-level information as referred above, ignored the context effect of the various countries. As individual trust could be affected not only by personal socioeconomic characteristics, but also by his environment where he resides, "analyzing only aggregated or only disaggregated data is apt to lead to misleading and erroneous conclusions” (Snijders and Bosker ${ }^{21}$, 2003, p. 16). This study will apply a multilevel approach and use the basic idea that the outcome variable-which is "trust" in our analysis—-has an individual as well as country aspect, to analyze within-country and between-country variances and test to what degree that formal and informal institutions would affect individual trust levels.

\section{Empirical Tests}

\section{1) Data}

Like most of previous studies, we use World Value Survey data to get individual-level information, which includes "trust”, “income level”, “education level”, “gender”, “age”, "size of town", and "religious belief". The dependent variable is a dummy equal to 1 if an individual replies "Most people can be trusted” to the question "Generally speaking,

\footnotetext{
${ }^{20}$ Raudenbush, S. W., A. S. Bryk (2002), Hierarchical Linear Models, California, Thousand Oaks: Sage Publication.

${ }^{21}$ Snijders, T. A. B., R. J. Bosker (2003), Multilevel Analysis: An Introduction to Basic and Advanced Multilevel Modeling, California, Thousand Oaks: Sage Publication.
} 
would you say that most people can be trusted or that you have to be very careful in dealing with people?". The validity of this "trust” measurement has been checked by Knack and Keefer (1997). They investigated empirical evidence and found that "trust is strikingly correlated across countries and regions with the number of wallets that were 'lost' and subsequently returned with their contents intact in an experiment conducted in various European nations and the United States. Values for trust are also consistent with anecdotal and case study evidence on trust across countries and regions” (Zak and Knack, 2001, p. 306). For the "religious belief” variable, we used two survey questions: "Belong to religious denomination” question ( 0 = No, 1 = Yes), and “Religious denomination” question which has yes/no answers for 86 religious denominations. The final religious denominations considered in this study are Muslim, Orthodox, Protestant, Roman Catholic, Oriental Religions which include Hindu, Confucianism, Buddhist, and Taoism, and Other as a reference group, which includes individuals who belong to other religious denominations and who do not have a religious belief ${ }^{22}$.

For the national level data, different data sources provide measurements of formal institutions, national economic performance indicators, and percentage of population who belong to certain religious denominations, etc. Table A1 shows detailed information for all the variables considered in this study. Total observations with complete individuallevel and national-level information for our analysis are 54,945. Table A2 and Table A3

\footnotetext{
${ }^{22}$ Of 54,945 total observations, about 79\% belong to five classifications of religious denominations used in this study; $18 \%$ of total surveyed individuals either have no religion or have religions that are not identified. And the rest of the $2.4 \%$ total observations belong to religious denominations which can be identified but are different from the 5 classifications. Since $2.4 \%$ is a small proportion, we treat them as a part of the reference group and only use five classifications of religious denominations in this study.
} 
in the Appendix display descriptive statistics and correlation information for these observations.

\section{2) Model Specification}

In this study, we wish to answer three questions to better understand institutions. The first question is concerned with country effects on trust, which is partly explained by formal institutions and other national characteristics. We will apply a random intercept model to try to provide empirical evidence to answer this question. The model is specified as:

$\left\{\begin{array}{c}Y_{i j}=\beta_{0_{j}}+\beta X+\varepsilon_{i j} \\ \beta_{0_{j}}=\beta_{00}+\gamma_{01} C_{j}+\mu_{0_{j}}\end{array}\right.$

In which,

$i$--- individual,

$j$--- country where surveyed individual lives,

$Y$--- Trust dummy variable, logistic conversion,

$X$--- individual-level variables,

$\beta_{0_{j}}$--- intercept with random effects,

$\beta$-- vector of coefficients for independent variables,

$C_{j}$--- variables to measure national-level characteristics for country $j$, which include formal institution, national economic performance, or demographic composition, etc.

$\mu_{0_{j}}$--- error term for intercept $\beta_{0}$, with distribution pattern:

$$
\left\lfloor\mu_{0_{j}}\right\rfloor \sim N\left(0, \Omega_{u}\right): \Omega_{u}=\left[\sigma_{\mu 0}^{2}\right]
$$

In this model, the values of $\gamma_{01} E_{j}+\mu_{0_{j}}$ are the main effects of the countries, conditional on an individual having a given $\mathrm{X}$-value and being in country $\mathrm{j}$. The $\mathrm{Y}$-value is expected to be $\gamma_{01} E_{j}+\mu_{0_{j}}$ higher than the average $\beta_{00}$ value, and varies randomly from country to 
country. In which, $\mu_{0_{j}}$ are the unexplained country effects to be randomly drawn from a population with zero mean and a priori unknown variance (Snijders and Bosker, 2003, p. 42).

The second question is to identify the effect of religion, one of several important informal institutions. We assume that trust will not only depend on individual religious beliefs, but it will also depend on the number of co-religionists in the country where the individual resides . One way to test this assumption is to use individual's religious belief and the percentage of population who belong to certain religious dominations in the country to differentiate context effects from religious institutions, as described in the following model:

$$
\left\{\begin{array}{c}
Y_{i j}=\beta_{0_{j}}+\beta X+\varepsilon_{i j} \\
\beta_{0_{j}}=\beta_{00}+\gamma_{01} \bar{R}_{j}+\mu_{0_{j}}
\end{array}\right.
$$

In which,

$X$--- individual-level variables, which include variables for individual religious belief; $\bar{R}_{j}$--- proportion of population who belongs to specific religious denomination in country $j$

While comparable to model (1), this second model specification has an important implication in terms of the concept of “effect from religion”. From this second assumption, effect of religion comes from two aspects: one is directly from individual religious belief which would be explained by within-group effects; and the second aspect is from religious organization. In this study, we use the proportion of population who 
belong to certain religious denominations as a proxy to estimate the second aspect of the effect of religion. We think that individual-level effects and group-level effects of religion could be very different. Some religious beliefs might promote trust at the individual level. But as a religious organization, it might not have a positive effect to promote trust due to various reasons, for instance, the respondent's levels of perceived alienation. Multilevel models can allow us to get a more complete picture of the effect of the "religion" factors. Previous studies did not distinguish these effects carefully, which might induce "shifts of meaning" and misinterpret effects of religious institutions (Snijders and Bosker, 2003, p. 13).

For the third research question, we assume that the effects of individual's religious belief, education level, income level, or the size of his community on trust could also differ between countries. The following model specification presents a general hierarchical model to address this question, by taking country-level indicators of formal and informal institutions into random effects to explain to what degree individuals may behave differently across different regions:

$$
\left\{\begin{array}{c}
Y_{i j}=\beta_{0_{j}}+\beta_{1_{j}} X_{1_{1 j}}+\beta X+\varepsilon_{i j} \\
\beta_{0_{j}}=\beta_{00}+\gamma_{01} E_{j}+\mu_{0_{j}} \\
\beta_{1_{j}}=\beta_{10}+\gamma_{11} E_{j}+\mu_{1_{j}}
\end{array}\right.
$$

In which,

$x_{1 i j}$---- individual-level variable refers: religious belief, or education level, or income level, or size of the community;

$X$--- other individual-level variables;

$\beta_{1_{j}}$--- slope with random effect; 
$\mu_{1_{j}}$--- error term for intercept $\beta_{1}$, with distribution pattern:

$\left\lfloor\mu_{1_{j}}\right\rfloor \sim N\left(0, \Omega_{u}\right): \Omega_{u}=\left[\sigma_{\mu 1}^{2}\right]$

\section{3) Results}

Model 1 in Table A4 contains not a single explanatory variable to provide the basic partition of the variability in the data between individual-level and country-level effects. According to this model, the total variance of trust can be decomposed as the sum of the individual-level and country-level variances. The estimates individual-level variance (0.9974) and country-level variance (0.6173) yield an intra-country correlation coefficient of $0.3823(=0.6173 /(0.9974+0.6173))$ to represent the proportion of variance in trust between countries. It also indicates that country does have significant contextual influence on individual trust level. The grouping according to country leads to an important similarity between the results of different individuals in the same country, although within-country differences are larger than between-country differences.

Model 2 adds individual-level explanatory variable, without considering country-level explanatory variables. As we compare with the fixed effects model, which has the same individual-level explanatory variables, random effect model (Model 2) generates a more powerful explanation, with deviation of 62387.2 vs. 65835.5 for the fixed effects model.

Compared to Model 2, Models 3 to 15 attempt to explain parts of country effects by using country-level variables which include formal institutions indicators or some other country-level variables to describe national economic performance or demographic structure. These indicators are Economic Freedom Indices, a corruption index, GDP per 
capita, educational attainment, Gini index, religious or ethnolinguistic fractionalization, etc. In general, these country-level explanatory variables show expected and significant influences on individual trust level. Higher levels of trust are supported by formal institutions with more economic freedom, higher quality of legal system to protect property rights, easier access to sound money, higher freedom to trade internationally, less red-tape regulations and less corruption. In addition, people who live in the countries which have higher GDP per capita, higher education attainment, and smaller Gini index values tend to have higher level trust too. Religious fractionalization and ethnolinguistic fractionalization do not show significant influence on individual trust levels, controlling for individual explanatory variables and unexplained country random effects.

Furthermore, by comparing country-level variances across different models in Table A4, we can "develop an index of proportion reduction in variance or, loosely speaking, the variance explained” by the country-level predictors (Bryk, Raudenbush ${ }^{23}, 1992$, p.65). From these indices listed in the Table A4, we can infer that corruption, access to sound money, index of legal systems and property rights, the Economic Freedom Index, GDP per capita, GINI index and regulation index have strong explanatory power for the country-level effects, as compared with other country-level indicators such as Ethnolinguistic Fractionalization, religious fractionalization, size of government index, and secondary education attainment rates.

To investigate the effect of religions, we use individual religious belief and percentage of population in the religious denominations to estimate two aspects of the effect of religions, as explained in the Type 2 model-specification, and estimated Models 16 to 19

${ }^{23}$ Bryk, A. S., S. W. Raudenbush (1992), Hierarchical Linear Models, California: Sage Publications. 
(Table A5 in the Appendix). Model results show that the effect of percentage of population in Muslim, Orthodox, and Catholic denominations is negative (only significant for Catholic denominations). The negative sign indicates that a randomly selected individual, controlled by other independent variables and unexplained country effects, tends to have a lower trust if he or she is in a country with a higher proportion of population in Muslims, Orthodox or Catholic denominations. In other words, the context effect of Muslim, Orthodox and Catholic religions contributes to bringing down the level of trust. Proportion of population belonging to a Protestant denomination is the only religious context effect that shows positive and significant impact on trust level, which means that the context effect of the Protestant religion provides an additional contribution over and above the effect of an individual's Protestant belief. These findings seem to provide some evidence to corroborate previous studies. For instance, Max Weber ${ }^{24}$ (1905) relates the rise of the capitalist economy to the Protestant belief in the ethic values of hard work and the fulfillment of one's worldly duties. The presence of these ethic values, for all its implicit concern with good citizenship, can make a positive contribution to deepen trust in an individual's mind. In the study of development differences across Italy, Putnam (1993) argues that the South owes its prevailing lack of trust to the strong Catholic tradition, "which emphasizes the vertical bond with the Church and tends to undermine the horizontal bond with fellow citizens”25 (Cuiso et al, 2003, p. 226). In a recent empirical study, Cuiso et $\mathrm{al}^{26}$ (2003) used World Value Survey data to investigate

\footnotetext{
${ }^{24}$ Weber, M (1905), The Protestant Ethic and The Spirit of Capitalism, London: Unwin.

${ }^{25}$ Putnam argues that "the Italian Church retains much of the heritage of the Counter-Reformation, including an emphasis on the ecclesiastical hierarchy and the traditional virtues of obedience and acceptance of one's station in life. Vertical bonds of authority are more characteristic of the Italian Church than horizontal bonds of fellowship" (p. 107).

${ }^{26}$ Guiso, Luigi, Paola Sapienza and Luigi Zingales (2003), People's Opium? Religion and Economic Attitudes, Journal of Monetary Economics, Vol. 50, No. 1, pp. 225-82.
} 
ideological differences cross religions in terms of individual's “economic attitudes toward cooperation, the government, working women, legal rules, thriftiness, and the market economy"27 (p. 225). They find that "Hindus and Muslim are less tolerant towards immigrants and other races, followed by Jews, Catholics and Protestants... Protestants are the only religious group that favors incentives” (p. 228). And “(o)bservant Catholics support private ownership twice as much as Protestants, while Muslims and Hindus are strongly against competition” (p. 228).

For the unexplained country effects in these models, they are significant and robust (see Models 1 to19), as indicated by significance tests for country-level variance of intercept random effects $\left(\operatorname{Var}\left(\mu_{0_{j}}\right)\right)$. Take Model 3 as an example. Country-level variance due to unexplained factors and the individual-level variance in this model are 0.3446 and 1.0014 respectively. These two numbers provide useful preliminary information about how much variation in the outcome lies within and between countries $^{28}$. In this case, these estimates indicate that even the residual variance between countries is substantially smaller than the residual variance at individual level (0.3446 vs. 1.0014); there is still a statistically significant amount of the variation (about 25 percent) comes from country effect.

For individual-level explanatory variables, if we assume that individuals are subject to effects based on their personal characteristics in the same degree, as this assumption implied in the Models 2 to 19, we find that personal education and income levels are

${ }^{27}$ In Guiso et al's paper, they also refer to studies done by Landes (1998) and Stulz and Williamson (2001), who point out "the culture of intolerance" and "the anti-usury culture" in Catholic tradition.

${ }^{28}$ Bryk, A. S., S. W. Raudenbush (1992), Hierarchical Linear Models, California: Sage Publications, p. 61. 
positively related with the level of trust. Also, older people tend to trust others more.

Size of the community where individuals reside, however, shows a negative association with trust. The smaller size of the town of residence tends to promote trust between individuals ${ }^{29}$. For individual-level religion variables which indicate whether the individual belongs to certain religious denominations, Muslim and Oriental religions are positively and significantly related with individual trust levels. Protestant religious belief tends to increase trust too, though not in a statistically significant degree. Catholic and Orthodox religions show negative impacts on individual trust level. To explain why the different religious believes have different degrees of influence on the level of trust needs a much deeper understanding of the spirit and activities involved in each religious denomination and is probably beyond our scope or capability.

And the assumption that individuals are subject to effects based on their personal characteristics in the same degree might be questionable. The impact on the trust level from individual's religious belief, education and income background, or the size of his community could differ from country to country. We test this hypothesis in Models 20 to 26. Perhaps the most notable features of the results could be summarized in the following:

\footnotetext{
${ }^{29}$ In two recent studies, Brueckner and Largey (2006) analyzed Social Capital Benchmark survey data and found that social interaction is negatively related with the neighborhood population density; Glaeser and Gottlieb examined the DDB Needham survey data and concluded that "(a)cross metropolitan areas, density is associated with less—not more-social capital” (p. 1297). As communities in U.S. suburban tend to be smaller in the total number of residence and of less denser area, our finding seems to be consistent with their studies.
} 
a) If we compare these seven random slope models with Model 3 in Table A4, the reduction in deviances is significant as compared with the Chi-squre distribution with 2 degrees of freedom ${ }^{30}$. We can infer that explanatory power is significantly enhanced by specifying the individual-level variables as random ${ }^{31}$; the use of random slope models can be justified.

b) Moreover, the significant slope variances in all of these models except Model 20 indicate that the relationship between the individual-level predictors and the trust indeed varies significantly from country to country. Table 1 below summarizes some statistical indicators for slope variances. And Table A7 in the Appendix provides intercept and slope coefficient for each country in the random slope models. Compared with the previous empirical studies which assume the association between the individual-level predicators and the level of trust is always the same across the countries, random slope models demonstrate that people may behave differently in different countries. For example, some previous studies find that higher individual income is positively related with the level of trust. On average, this might be a reasonable finding. Our study also supports this finding through the positive and significant slope coefficients for individuallevel income variable in all the models. However, once we take contextual effect or country effect into consideration, the relationship between the income and trust variables varies across countries. Individual with higher income level may be more likely to trust less in some countries like India, South Africa, Turkey, Egypt, Chile, Bangladesh, etc. This also applies to education. Our results show that people who obtained higher

\footnotetext{
${ }^{30}$ With two degrees of freedom and a .05 level of significance, the critical chi-square value is 5.99.

${ }^{31}$ Bryk, A. S., S. W. Raudenbush (1992), Hierarchical Linear Models, California: Sage Publications, p. 7576.
} 
education tend to be more likely to have a skeptical view in some developing countries, for instance, in Bangladesh, Egypt, etc. For the random effect on the religions considered in our study, individuals with Muslim religious belief tend to have a higher probability to be trusting in those countries with more co-religionists. The relationship with the size of religious denominations for Orthodox, Protestant and Catholic seems not as obvious as

Table 1 Interpretation for Random Slope Effect

\begin{tabular}{|l|l|c|c|c|c|c|}
\hline & $\begin{array}{c}\text { Slope which } \\
\text { has random } \\
\text { effect }\end{array}$ & $\begin{array}{c}\text { Slope } \\
\text { Standard } \\
\text { Dev. }\end{array}$ & $\begin{array}{c}\text { Low range } \\
\text { of slope } \\
\text { coefficient }\end{array}$ & $\begin{array}{c}\text { High range of } \\
\text { slope } \\
\text { coefficient }\end{array}$ & $\begin{array}{c}\text { correlation } \\
\text { between random } \\
\text { slope and } \\
\text { intercept }\end{array}$ & $\begin{array}{c}\text { correlation } \\
\text { within } \\
\text { country }\end{array}$ \\
\hline Model 20 & Muslim & 0.4227 & -0.7042 & 0.5856 & -0.0508 & 0.2364 \\
\hline Model 21 & Orthodox & 0.8991 & -1.2398 & 1.4270 & 0.0863 & 0.2108 \\
\hline Model 22 & Protestant & 0.4252 & -0.3698 & 1.0277 & -0.1603 & 0.2683 \\
\hline Model 23 & Catholic & 0.2608 & -0.4514 & 0.3615 & -0.3599 & 0.2837 \\
\hline Model 24 & Income & 0.0639 & -0.0846 & 0.1724 & 0.3397 & 0.2301 \\
\hline Model 25 & Education & 0.1051 & -0.1759 & 0.3588 & 0.2659 & 0.2330 \\
\hline Model 26 & Size of Town & 0.0598 & -0.1759 & 0.0728 & -0.1962 & 0.2969 \\
\hline
\end{tabular}

for the Muslim religion, even though the associations between these three religions and the level of trust do change across the countries, as illustrated in Table A7. According to the similarity in terms of the effects from religions at individual level and religious compositions across the country, we clustered countries into 7 groups, and listed them in the Table A8 in the Appendix. We also summarize the difference between previous studies and our multilevel approach in the Table A9.

c) With regard to the slopes of individual-level variables of Muslim belief and size of town, once they are set as the random variables in Models 20 26, they are no longer significantly related with level of trust. This change indicates that contextual effects from 
the different countries tend to override the individual-level effect from Muslim religion or from size of town of residence

d) As we use the Economic Freedom Index to discover whether countries with high Economic Freedom Index values differ from countries with low Economic Freedom Index values in terms of the strength of association between individual-level predicators and the level of trust within them, we find that there is a tendency for countries with more economic freedom to have larger slopes than do countries with low economic freedom for the three individual-level variables: income, education and size of town, with statistically significant coefficients 0.03561, 0.07537 and 0.0207 in Models 24, 25 and

26. These positive and significant coefficients indicate that countries with higher levels of economic freedom for an individual have a higher within-country effect from income, education and size of town variables. Or in other words, higher levels of trust tend to be achieved more by the individuals with more income, or higher education levels or in smaller towns than by individuals with lower income, education levels or residing in the bigger towns in countries with more economic freedom.

\section{Conclusions}

It is a truism that levels of trust between individuals are profoundly important. Recent research corroborates the idea that there are identifiable variations in levels of trust from individual to individual as well as from place to place and culture to culture. Yet this is not enough. Trust is, by definition, other-directed and we must know more about how the context within which the individual finds himself matters as we investigate the 
determinants of trust. This study is the first, to our knowledge, to empirically test these context effects. And the very foundation of these context effects is concerned with macro-level institutions, either formal or informal institutions that shape individual incentives and behavior. By taking into consideration the micro-unit and macro-unit hierarchical structures that both research questions and the data itself involve, our study demonstrates that context matters, and institutions matter -- and moreover, in what pattern that these institutions matter by applying multilevel level methods to available data sources. 


\section{Reference:}

Beito, D. T., P. Gordon, A. Tabarrok (2002), Voluntary City, Michigan: The University of Michigan Press.

Berggren, N., H. Jordahl (2006), Free to Trust: Economic Freedom and Social Capital, Kyklos, Vol. 59, No. 2, pp. 141-169.

Beugelsdijk, S. and T. von Schaik (2001), Social Capital and Regional Economic Growth, CentER Discussion Paper, December.

Brueckner, J. K. and A. G. Largey (2006), Social Interaction and Urban Sprawl, http://www.socsci.uci.edu/ jkbrueck/socinteract.pdf.

Bryk, A. S., S. W. Raudenbush (1992), Hierarchical Linear Models, California: Sage Publications.

Fukuyama, F. (1995), Trust, New York: Free Press.

Glaeser, E. L., D. I. Laibson, J. A. Scheinkman, C. L. Soutter (2000), Measuring Trust, The Quarterly Journal of Economics, Vol. 115, No. 3, pp. 811-846.

Glaeser, E. L. and J. D. Gottlieb (2006), Urban Resurgence and the Consumer City, Urban Studies, Vol. 43, No. 8, pp. 1275-1299.

Guiso, L., P. Sapienza and L. Zingales (2003), People's Opium? Religion and Economic Attitudes, Journal of Monetary Economics, Vol. 50, No. 1, pp. 225-82.

Guiso, L., P. Sapienza and L. Zingales (2006), Does Culture Affect Economic Outcomes? Journal of Economic Perspectives, Vol. 20, No. 2, pp. 23-48

Knack, S., and P. Keefer (1997), Does Social Capital Have an Economy Payoff ? A Cross-Country Investigation, Quarterly Journal of Economics, Vol. 112, No. 4, pp. 1251-1288.

La Porta, R., F. Lopez-de-Silanes, A. Shleifer, and R. Vishny (1997), Trust in Large Organizations, American Economic Review Papers and Proceedings, Vol. 87, No. 2, pp. 333-338.

Putnam, R., Leonardi, R., and Nanetti, R.Y. (1993), Making democracy work. Princeton, New Jersey: Princeton University Press.

Raudenbush, S. W., A. S. Bryk (2002), Hierarchical Linear Models, California, Thousand Oaks: Sage Publication. 
Snijders, T. A. B., R. J. Bosker (2003), Multilevel Analysis: An Introduction to Basic and Advanced Multilevel Modeling, California, Thousand Oaks: Sage Publication.

Tabellini, Guido (2005), Culture and institutions: economic development in the regions of Europe, working paper

Uslaner, Eric M. (2004), Trust, Democracy, and Governnance: Can Government Policies Influence Generalized Trust? in Dietlind Stolle and Marc Hooghe, eds., Generating Social Capital (Palgrave, 2004), http://www.bsos.umd.edu/gvpt/uslaner/generating5uslaner.doc.

Uslaner, Eric M. (2002), The Moral Foundations of Trust, Cambridge University Press.

Weber, M (1905), The Protestant Ethic and The Spirit of Capitalism, London: Unwin

Wolf, C. Jr. (1995), The Limits of Trust, The National Interest, Iss. 41, pp. 95.

Zak, P. J. and S. Knack (2001), Trust and Growth, The Economic Journal, 111 (April), p. 295-321. 


\section{Appendix}

Table A1 Variable Description

\begin{tabular}{|c|c|c|c|}
\hline & $\begin{array}{c}\text { Spatial } \\
\text { Level }\end{array}$ & Variable & Variable Description and Note \\
\hline $\begin{array}{l}\text { Depende } \\
\text { nt } \\
\text { Variable }\end{array}$ & \multirow{7}{*}{ 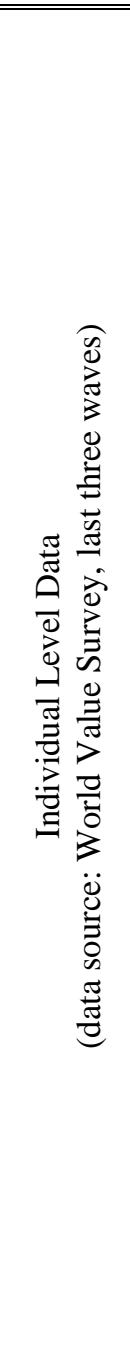 } & Trust & $\begin{array}{l}\text { Dummy variable: } \\
\text { Value is based on the question: "Generally speaking, would you say that } \\
\text { most people can be trusted or that you need to be very careful in dealing } \\
\text { with people?” } \\
0=\text { "Can't be too careful” } \\
1 \text { = "Most people can be trusted" }\end{array}$ \\
\hline \multirow[t]{14}{*}{$\begin{array}{l}\text { Independ } \\
\text { ent } \\
\text { Variable }\end{array}$} & & Education level & $\begin{array}{l}1 \text { = "Inadequately completed elementary school" } \\
2 \text { = "Completed (compulsory) elementary school" } \\
3 \text { = "Incomplete secondary school: technical/vocational type/(Comp" } \\
4 \text { = "Complete secondary school: technical/vocational type/Seconda" } \\
5 \text { = "Incomplete secondary: university-preparatory type/Secondary," } \\
6 \text { = "Complete secondary: university-preparatory type/Full seconda" } \\
7 \text { = "Some university without degree/Higher education- lower-leve" } \\
8 \text { = "University with degree/Higher education - upper-level tertia" }\end{array}$ \\
\hline & & Income level & Each country has 10 scales of income: $1-10$ \\
\hline & & Size of town & $\begin{array}{l}1=2000 \text { and less } \\
2=2000-5000 \\
3=5000-10000 \\
4=10000-20000 / 10000-25000 \\
5=20000-50000 \\
6=50000-100000 \\
7=100000-500000 \\
8=500000 \text { and more }\end{array}$ \\
\hline & & Age & Real age number \\
\hline & & Gender & $\begin{array}{l}0=\text { male } \\
1=\text { female }\end{array}$ \\
\hline & & Religion & $\begin{array}{l}\text { Dummy variable: } \\
\text { Muslim } \\
\text { Orthodox } \\
\text { Protestant } \\
\text { Roman Catholic } \\
\text { Oriental religions include: Hindu, Confucianism, Buddhist, Tao } \\
\text { Other (reference group, including non-religious people) } \\
\end{array}$ \\
\hline & \multirow{8}{*}{ 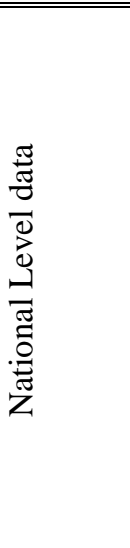 } & $\begin{array}{l}\text { Economic Freedom Index } \\
\text { (EFI) }\end{array}$ & \multirow{6}{*}{$\begin{array}{l}\text { All of them are from Fraser Institute's Economic Freedom Index table, } \\
\text { for corresponded years } \\
\text { Because some surveys were done in the years which are one-year away } \\
\text { from the year of Economic Freedom Index value. In these cases, EFI } \\
\text { would be assigned to the WVS data. For instance, } 1999 \text { WVS data for } \\
\text { some countries would get } 2000 \text { EFI index value. }\end{array}$} \\
\hline & & Size of government (EFI1) & \\
\hline & & $\begin{array}{l}\text { Legal system \& Property } \\
\text { Rights (EFI2) }\end{array}$ & \\
\hline & & Sound money (EFI3) & \\
\hline & & $\begin{array}{l}\text { Freedom to trade } \\
\text { internationally (EFI4) }\end{array}$ & \\
\hline & & Regulation (EFI5) & \\
\hline & & GINI index & \\
\hline & & GDP per capita & $\begin{array}{l}\text { GDP per capita for corresponded years and countries } \\
\text { Source: Penn World Table }\end{array}$ \\
\hline
\end{tabular}




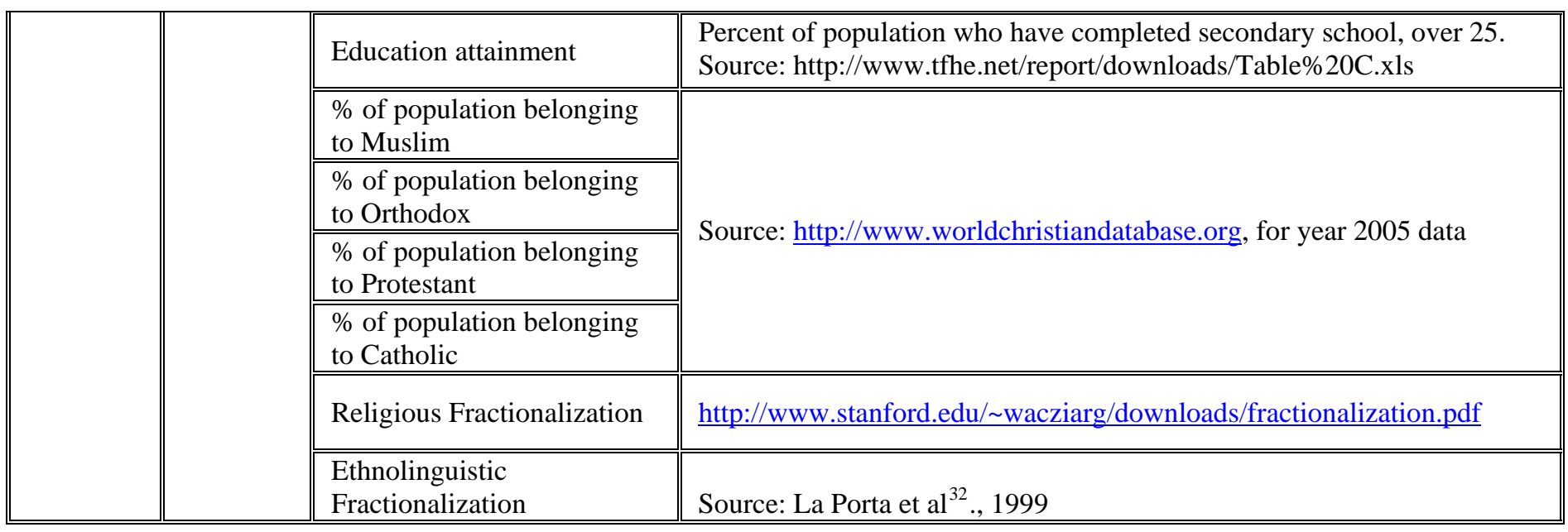

${ }^{32}$ R La Porta, F Lopez-de-Silanes, A Shleifer and R Vishny (1999), The Quality of Government, Journal of Law, Economics, and Organization, Vol. 15, No. 1, pp. 222-279. 
Table A2 Descriptive Statistics for Trust Data (54,945 observations)

Descriptive Statistics for Individual Level Data

\begin{tabular}{|l|r|r|r|r|r|}
\hline & $\mathrm{N}$ & Minimum & Maximum & \multicolumn{1}{c|}{ Mean } & Std. Deviation \\
\hline Trust & 54945 & 0 & 1 & .31 & .462 \\
Income Scale & 54945 & 1.0 & 10.0 & 4.620 & 2.5048 \\
Education Level & 54945 & 1 & 8 & 4.37 & 2.329 \\
Age & 54945 & 15 & 99 & 41.40 & 16.059 \\
Gender & 54945 & 0 & 1 & .50 & .500 \\
Size of Town & 54945 & 1 & 9 & 5.18 & 2.439 \\
Muslim & 54945 & 0 & 1 & .17 & .373 \\
Orthodox & 54945 & 0 & 1 & .05 & .213 \\
Protestant & 54945 & 0 & 1 & .15 & .358 \\
Catholic & 54945 & 0 & 1 & .31 & .464 \\
Oriental Religion & 54945 & 0 & 1 & .09 & .287
\end{tabular}

\section{Descriptive Statistics for National Level Data}

\begin{tabular}{|l|r|r|r|r|r|}
\hline & \multicolumn{1}{|c|}{ N } & Minimum & Maximum & \multicolumn{1}{c|}{ Average } & \multicolumn{1}{c|}{ st dev } \\
\hline Economic Freedom Index & 46 & 4.221 & 8.566 & 6.668 & 1.119 \\
\hline Size of Government & 46 & 2.288 & 8.636 & 5.706 & 1.528 \\
\hline Legal System \& Property Rights & 46 & 2.892 & 9.625 & 6.674 & 2.061 \\
\hline Sound money & 46 & 0.000 & 9.839 & 7.602 & 2.512 \\
\hline Freedom to Trade internatinally & 46 & 3.178 & 9.005 & 7.161 & 1.401 \\
\hline Regulation & 46 & 4.006 & 8.235 & 6.196 & 1.032 \\
\hline GDP(,000) & 46 & 1.528 & 34.365 & 13.655 & 9.899 \\
\hline Gini index & 37 & 24.700 & 59.300 & 36.741 & 9.528 \\
\hline Ethnolinguistic Fractionalization & 37 & 0.000 & 0.831 & 0.189 & 0.234 \\
\hline Religious Fractionalization & 37 & 0.005 & 0.860 & 0.380 & 0.240 \\
\hline Education & 37 & 4.700 & 63.200 & 28.649 & 15.212 \\
\hline Muslim (\%) & 37 & 0.000 & 0.973 & 0.173 & 0.318 \\
\hline Orthodox (\%) & 37 & 0.000 & 0.912 & 0.086 & 0.238 \\
\hline Protestants (\%) & 37 & 0.000 & 0.899 & 0.165 & 0.265 \\
\hline Catholics (\%) & 37 & 0.000 & 0.966 & 0.382 & 0.376 \\
\hline
\end{tabular}


Table A3 Correlation Matrix

\begin{tabular}{|c|c|c|c|c|c|c|c|c|c|c|c|}
\hline & TRUST & $\begin{array}{c}\text { INCM_SCA } \\
\text { LE }\end{array}$ & \begin{tabular}{|c|} 
EDUCATIO \\
$\mathrm{N}$
\end{tabular} & AGE & GENDER & TOWN & MUSLIM & ORTHD & PROTET & CATHLIC & ORIENT \\
\hline TRUST & \pm & & & & & & & & & & \\
\hline INCM_SCALE & $.117(* *)$ & 1 & & & & & & & & & \\
\hline EDUCATION & $\left..0799^{(*}\right)$ & $.373(* *)$ & 1 & & & & & & & & \\
\hline AGE & $.030(* *)$ & $-.066\left({ }^{* *}\right)$ & $-.246(\star *)$ & 1 & & & & & & & \\
\hline GENDER & $-.014(* \star)$ & $-.046(* *)$ & $-.063(* *)$ & $-.013(* \star)$ & 1 & & & & & & \\
\hline TOWN & $-.035(* *)$ & $.115(* *)$ & $.246(* *)$ & $-.050(* *)$ & $.021(* *)$ & 1 & & & & & \\
\hline MUSLIM & $-.019(* \star)$ & -0.002 & $-.101(* *)$ & $-.113(* \star)$ & $-.028(* *)$ & $-.156\left(^{\star \star}\right)$ & 1 & & & & \\
\hline ORTHD & $-.060(* *)$ & $.047(\star \star)$ & $.065(* *)$ & $.036(* *)$ & $.025(* *)$ & $.026(* \star)$ & $-.100{ }^{(* *)}$ & 1 & & & \\
\hline PROTET & $.112(* *)$ & $.036(* *)$ & $.032(* *)$ & $.102(* *)$ & $.027(* *)$ & $-.031(* \star)$ & $\left.-.189{ }^{(\star \star}\right)$ & $-.094(* \star)$ & 1 & & \\
\hline CATHLIC & $-.076(* \star)$ & $-.022(* \star)$ & $-.036(* *)$ & $.086(* *)$ & $.048(* *)$ & $.037(* \star)$ & $-.303(* *)$ & $-.151(\star \star)$ & $-.285(\star \star)$ & 1 & \\
\hline ORIENT & $.042(* *)$ & $-.085{ }^{(* *)}$ & $.047(* *)$ & $-.092(* \star)$ & $-.041(* *)$ & $-.015\left(^{\star \star}\right)$ & $-.142(* \star)$ & $-.071(* \star)$ & $-.133(* *)$ & $-.213(* \star)$ & 1 \\
\hline EFI & $.160(* *)$ & $.198(* *)$ & $.044(* *)$ & $.179(\star *)$ & $.041(* *)$ & -0.004 & $\left.-.208{ }^{(\star \star}\right)$ & $-.175\left(^{* \star}\right)$ & $.322(* *)$ & $.078(* *)$ & $-.295(\star \star)$ \\
\hline EFI1 & $-.079(* \star)$ & $-.013(* *)$ & $-.025(\star *)$ & $-.163(* \star)$ & $-.014(* *)$ & 0.005 & $.292(* *)$ & $-.117\left({ }^{\star \star}\right)$ & $-.170(* \star)$ & $\left.-.069{ }^{(\star *}\right)$ & 0.005 \\
\hline EFI2 & $\left..1599^{(* *}\right)$ & $.126(\star *)$ & $.037(* *)$ & $.218(* *)$ & $.041(\star \star)$ & $-.009\left(^{*}\right)$ & $-.367(\star \star)$ & $-.092(* *)$ & $.396(* *)$ & $.099\left(^{* *}\right)$ & $-.214(\star \star)$ \\
\hline EFI3 & $.174(* *)$ & $.193(* *)$ & $.024(* *)$ & $.132(* *)$ & $.017(\star \star)$ & $-.044(* \star)$ & $-.028(\star \star)$ & $-.205(* \star)$ & $.209\left(^{(\star)}\right.$ & $-.017(* *)$ & $-.112(* \star)$ \\
\hline EFI4 & $\left..100{ }^{(* *}\right)$ & $.161(\star *)$ & $.042(* \star)$ & $.210(* *)$ & $.054(\star \star)$ & $.023(\star \star)$ & $-.266\left(^{(\star *}\right)$ & 0.006 & $.229\left(^{\star \star}\right)$ & $.225(* *)$ & $-.473(* *)$ \\
\hline EFI5 & $.111(* *)$ & $.153(* \star)$ & $.086(* \star)$ & $.157(* *)$ & $.041(\star \star)$ & $\left..060^{(*}\right)$ & $-.381(* \star)$ & $-.124(\star \star)$ & $.384\left({ }^{* *}\right)$ & $.043\left({ }^{* *}\right)$ & $-.241\left({ }^{\star \star}\right)$ \\
\hline GDPPWT & $.144(* *)$ & $.173(* *)$ & $.072(* *)$ & $.224(* *)$ & $.047(\star *)$ & $.016\left({ }^{\star *}\right)$ & $-.394(* *)$ & $-.082\left({ }^{\star *}\right)$ & $.350(* *)$ & $.165^{(* *)}$ & $-.324\left({ }^{\star *}\right)$ \\
\hline GINI & $-.161(* *)$ & $-.123\left({ }^{* \star}\right)$ & $.014(* *)$ & $-.126(* *)$ & 0.007 & $.215(* *)$ & $\left.-.148{ }^{(\star *}\right)$ & $-.088\left(^{* *}\right)$ & $-.058(\star \star)$ & $.249{ }^{(*)}$ & $-.152(* *)$ \\
\hline MUSLAVN & $-.029(* *)$ & $-.010\left(^{*}\right)$ & $-.123(* *)$ & $\left.-.138{ }^{(\star \star}\right)$ & $-.031(* *)$ & $-.139(\star \star)$ & $.772(* *)$ & $-.084(* \star)$ & $-.223(\star \star)$ & $-.350(* \star)$ & $-.036(* \star)$ \\
\hline ORTHODAVN & $-.053(* *)$ & $.081(\star \star)$ & $.069(* \star)$ & $.040(* *)$ & $.021(\star \star)$ & 0.001 & $-.010\left(^{*}\right)$ & $.812(\star \star)$ & $-.101(* \star)$ & $-.164(* \star)$ & $-.095(* *)$ \\
\hline PROTESTAVN & $.184(* *)$ & $.064(\star *)$ & $.035(* *)$ & $.091(* *)$ & $.013(\star \star)$ & $-.037\left(^{* *}\right)$ & $-.237(\star \star)$ & $-.083(* *)$ & $.589\left(^{* \star}\right)$ & $-.137\left(^{* *}\right)$ & $-.152\left({ }^{\star *}\right)$ \\
\hline CATHAVN & $-.104(* \star)$ & $-.043(* *)$ & $-.022(\star *)$ & $.058(* *)$ & $.026(* \star)$ & $.126(\star \star)$ & $-.413(\star \star)$ & $-.165(* *)$ & $-.193(* *)$ & $.646(* *)$ & $-.292(\star \star)$ \\
\hline RELIGFRACT & $.028(* *)$ & $.017(* \star)$ & $.076\left(^{* \star}\right)$ & $.121(* *)$ & $.027\left(^{\star \star}\right)$ & $.093(* \star)$ & $-.413\left({ }^{\star \star}\right)$ & $-.075\left(^{\star \star}\right)$ & $.289\left({ }^{\star *}\right)$ & $.025\left(^{(*)}\right.$ & $\left.-.069{ }^{(\star \star}\right)$ \\
\hline ETHLIG & 0 & $-.100(* *)$ & $.060(* *)$ & $-.062\left(^{* *}\right)$ & $-.034(* *)$ & -0.001 & $-.178(* *)$ & -.109 (**) & 0.001 & $-.154(* *)$ & $.520(* *)$ \\
\hline
\end{tabular}

\begin{tabular}{|c|c|c|c|c|c|c|c|c|c|c|c|c|c|}
\hline & EFI & EFI1 & $\mathrm{EFI} 2$ & EFI3 & EFI4 & EFI5 & \begin{tabular}{|c|} 
GDPPW \\
$T$
\end{tabular} & GINI & \begin{tabular}{|c|} 
MUSLAV \\
$\mathrm{N}$
\end{tabular} & \begin{tabular}{|c|} 
ORTHOD \\
AVN
\end{tabular} & \begin{tabular}{|c|} 
PROTES \\
TAVN
\end{tabular} & $\begin{array}{l}\text { CATHAV } \\
\mathrm{N}\end{array}$ & \begin{tabular}{|c|} 
RELIGFR \\
ACT
\end{tabular} \\
\hline EFI & 1 & & & & & & & & & & & & \\
\hline EFI1 & $-.137(* \star)$ & 1 & & & & & & & & & & & \\
\hline EFI2 & $.815(* \star)$ & $-.479(* \star)$ & 1 & & & & & & & & & & \\
\hline EFI3 & $.864\left({ }^{\star \star}\right)$ & $-.212(* \star)$ & $.595(* \star)$ & 1 & & & & & & & & & \\
\hline EFI4 & $.774(* \star)$ & $-.355(* \star)$ & $.660(* \star)$ & $.564(* \star)$ & 1 & & & & & & & & \\
\hline EFI5 & $.842(* *)$ & $-.195(\star \star)$ & $.770(* \star)$ & $.610(* \star)$ & $.614\left({ }^{(\star}\right)$ & 1 & & & & & & & \\
\hline GDPPWT & $.824(* \star)$ & $-.434(* \star)$ & $.905(* \star)$ & $\left..606{ }^{(\star \star}\right)$ & $\left..770^{(* \star}\right)$ & $.755\left(^{\star \star *}\right)$ & 1 & & & & & & \\
\hline GINI & $-.200\left({ }^{\star \star}\right)$ & $.464(* \star)$ & $-.276\left({ }^{\star \star}\right)$ & $-.412(* \star)$ & $-.121(* \star)$ & $-.035(\star \star)$ & $-.255(\star \star)$ & 1 & & & & & \\
\hline MUSLAVN & $-.293(* \star)$ & $.369(* \star)$ & $-.497(* \star)$ & $-.046(* *)$ & $-.427(* \star)$ & $-.422(* *)$ & $-.484(* *)$ & $-.213\left({ }^{\star \star}\right)$ & 1 & & & & \\
\hline ORTHODAVN & $-.182(* *)$ & $-.132(\star \star)$ & $-.107\left(^{\star \star}\right)$ & $-.197(\star \star)$ & $.018(* *)$ & $-.150(* \star)$ & $-.112(* *)$ & $-.144(\star \star)$ & $-.034\left({ }^{* *}\right)$ & 1 & & & \\
\hline PROTESTAVN & $.376\left(^{(* *}\right)$ & $-.341\left({ }^{\star \star}\right)$ & $.542(* \star)$ & $.246(\star \star)$ & $.330(* *)$ & $.400(* *)$ & $.488(* *)$ & $-.223(* *)$ & $-.293(\star \star)$ & $-.125(\star *)$ & 1 & & \\
\hline CATHAVN & $.071(* \star)$ & $-.103(* \star)$ & $.092(* \star)$ & $-.077(* *)$ & $.341(* *)$ & $.042(* *)$ & $.201(* *)$ & $.395(* \star)$ & $-.517\left(^{(*)}\right)$ & $-.239\left(^{(\star *}\right)$ & $-.219\left({ }^{\star *}\right)$ & 1 & \\
\hline RELIGFRACT & $.419\left({ }^{* *}\right)$ & $-.031(* \star)$ & $.527\left({ }^{\star \star}\right)$ & $.166\left(^{(\star *}\right)$ & $.213(* \star)$ & $.597(* \star)$ & $.471(* \star)$ & $.211\left({ }^{\star \star}\right)$ & -.418 (**) & $-.099\left({ }^{(\star *}\right)$ & $.172^{(* *)}$ & $-.027(* \star)$ & 1 \\
\hline ETHLIG & $-.208\left({ }^{\star \star}\right)$ & $.098(* *)$ & $-.281(* \star)$ & $-.067(\star \star)$ & $-.324(\star *)$ & $-.089\left({ }^{\star \star}\right)$ & $-.300(* *)$ & $.066(* \star)$ & $-.070(* *)$ & $-.169\left({ }^{* *}\right)$ & $-.129(* *)$ & $-.269\left({ }^{\star \star}\right)$ & $.222(* \star)$ \\
\hline
\end{tabular}


Table A4 Random effect on INTERCEPT only

\begin{tabular}{|c|c|c|c|c|c|c|c|c|}
\hline \multirow[b]{2}{*}{ Variable } & \multicolumn{2}{|c|}{$\begin{array}{c}\text { Model } 1 \\
\text { (Empty model) }\end{array}$} & \multicolumn{2}{|c|}{$\begin{array}{c}\text { Model } 2 \\
\text { (Without explanation of } \\
\text { random intercept) }\end{array}$} & \multicolumn{2}{|c|}{$\begin{array}{c}\text { Model 3 } \\
\text { (Random intercept } \\
\text { explained by EFI) } \\
\end{array}$} & \multicolumn{2}{|c|}{$\begin{array}{c}\text { Model 4 } \\
\text { (Random intercept } \\
\text { explained EFI1) } \\
\end{array}$} \\
\hline & Estimate & S.E. & Estimate & S.E. & Estimate & S.E. & Estimate & S.E. \\
\hline \multicolumn{9}{|l|}{ Fixed Effect } \\
\hline Intercept & -0.8580 & 0.1164 & -1.3745 & 0.1191 & -3.993 & 0.5406 & -0.484 & 0.4053 \\
\hline Income & & & 0.05246 & 0.004451 & 0.05224 & 0.004451 & 0.05247 & 0.004451 \\
\hline Education & & & 0.05955 & 0.00497 & 0.05964 & 0.004969 & 0.05958 & 0.00497 \\
\hline Gender & & & -0.01084 & 0.01961 & -0.011 & 0.01962 & -0.01079 & 0.01961 \\
\hline Age & & & 0.003305 & 0.000657 & 0.003 & 0.000657 & 0.003291 & 0.000657 \\
\hline Size of Town & & & -0.02789 & 0.004571 & -0.02803 & 0.004569 & -0.02784 & 0.004571 \\
\hline Muslim & & & 0.1546 & 0.06772 & 0.1773 & 0.06743 & 0.1612 & 0.0677 \\
\hline Orthodox & & & -0.185 & 0.0909 & -0.1711 & 0.09058 & -0.1902 & 0.09079 \\
\hline Protestant & & & 0.06192 & 0.03844 & 0.0592 & 0.03842 & 0.06087 & 0.03845 \\
\hline Catholic & & & -0.0568 & 0.03078 & -0.05857 & 0.03075 & -0.05723 & 0.03077 \\
\hline Oriental Religions & & & 0.2008 & 0.07189 & 0.2266 & 0.07178 & 0.2051 & 0.07186 \\
\hline Economic Freedom Index & & & & & 0.3923 & 0.07952 & & \\
\hline \multicolumn{9}{|l|}{ Ethnolinguistic Fractionalization } \\
\hline Size of Government & & & & & & & -0.1562 & 0.06819 \\
\hline \multicolumn{9}{|l|}{ Random Effect } \\
\hline \multicolumn{9}{|l|}{ Level-one variance } \\
\hline Var (residual for level one) & 0.9974 & 0.00602 & 1.0011 & 0.006 & 1.0014 & 0.006045 & 1.0011 & 0.006043 \\
\hline \multicolumn{9}{|l|}{ Level-two random effects } \\
\hline Intercept Random Effect $\left(\mathrm{U}_{0 . \mathrm{ij}}\right)$ & 0.6173 & 0.1317 & 0.5265 & 0.1132 & 0.3446 & 0.07522 & 0.4806 & 0.1046 \\
\hline $\begin{array}{l}\text { Proportion variance explained by country-level } \\
\text { predicators }\end{array}$ & & & & & 0.3455 & & 0.0872 & \\
\hline Deviance & 62831.7 & & 62387.2 & & 62387.3 & & 62387.2 & \\
\hline
\end{tabular}


Table A4 Random effect on INTERCEPT only (cont.)

\begin{tabular}{|c|c|c|c|c|c|c|c|c|}
\hline \multirow[b]{2}{*}{ Variable } & \multicolumn{2}{|c|}{$\begin{array}{c}\text { Model 5 } \\
\text { (Random intercept } \\
\text { explained EFI2) } \\
\end{array}$} & \multicolumn{2}{|c|}{$\begin{array}{c}\text { Model } 6 \\
\text { (Random intercept } \\
\text { explained EFI3) } \\
\end{array}$} & \multicolumn{2}{|c|}{$\begin{array}{c}\text { Model } 7 \\
\text { (Random intercept } \\
\text { explained by EFI4) }\end{array}$} & \multicolumn{2}{|c|}{$\begin{array}{c}\text { Model } 8 \\
\text { (Random intercept } \\
\text { explained by EFI5) }\end{array}$} \\
\hline & Estimate & S.E. & Estimate & S.E. & Estimate & S.E. & Estimate & S.E. \\
\hline \multicolumn{9}{|l|}{ Fixed Effect } \\
\hline Intercept & -2.8196 & 0.3047 & -2.7226 & 0.2845 & -2.9833 & 0.5239 & -3.3948 & 0.6046 \\
\hline Income & 0.05237 & 0.00445 & 0.05224 & 0.004452 & 0.05232 & 0.004452 & 0.05237 & 0.004451 \\
\hline Education & 0.05966 & 0.004969 & 0.05964 & 0.004969 & 0.0596 & 0.00497 & 0.05958 & 0.00497 \\
\hline Gender & -0.01088 & 0.01961 & -0.01093 & 0.01962 & -0.01099 & 0.01961 & -0.01096 & 0.01962 \\
\hline Age & 0.003278 & 0.000657 & 0.003286 & 0.000657 & 0.003283 & 0.000657 & 0.003296 & 0.000657 \\
\hline Size of Town & -0.02796 & 0.004569 & -0.02793 & 0.004569 & -0.02795 & 0.00457 & -0.02803 & 0.004571 \\
\hline Muslim & 0.1863 & 0.06759 & 0.1587 & 0.06709 & 0.1719 & 0.06784 & 0.1767 & 0.06791 \\
\hline Orthodox & -0.1774 & 0.09041 & -0.1747 & 0.09051 & -0.185 & 0.09075 & -0.1747 & 0.0908 \\
\hline Protestant & 0.05685 & 0.03844 & 0.06109 & 0.03841 & 0.06069 & 0.03844 & 0.05957 & 0.03844 \\
\hline Catholic & -0.05877 & 0.03075 & -0.05834 & 0.03076 & -0.05841 & 0.03077 & -0.05682 & 0.03077 \\
\hline Oriental Religions & 0.2273 & 0.07177 & 0.2098 & 0.0715 & 0.2229 & 0.07219 & 0.2197 & 0.07201 \\
\hline \multicolumn{9}{|l|}{ Economic Freedom Index } \\
\hline \multicolumn{9}{|l|}{ Ethnolinguistic Fractionalization } \\
\hline \multicolumn{9}{|l|}{ Size of Government } \\
\hline Legal System and Property Rights & 0.216 & 0.04294 & & & & & & \\
\hline Sound Money & & & 0.1773 & 0.03497 & & & & \\
\hline Freedom to Trade Internationally & & & & & 0.2245 & 0.07143 & & \\
\hline Regulation & & & & & & & 0.3256 & 0.09579 \\
\hline \multicolumn{9}{|l|}{ Random Effect } \\
\hline \multicolumn{9}{|l|}{ Level-one variance } \\
\hline Var (residual for level one) & 1.0011 & 0.006043 & 1.0015 & 0.006045 & 1.0012 & 0.006043 & 1.0013 & 0.006044 \\
\hline \multicolumn{9}{|l|}{ Level-two random effects } \\
\hline Intercept Random Effect $\left(\mathrm{U}_{0 . \mathrm{ij}}\right)$ & 0.3395 & 0.07419 & 0.3374 & 0.07376 & 0.4384 & 0.09562 & 0.4263 & 0.09265 \\
\hline $\begin{array}{l}\text { Proportion variance explained by country-level } \\
\text { predicators }\end{array}$ & 0.3552 & & 0.3592 & & 0.1673 & & 0.1903 & \\
\hline Deviance & 62387.3 & & 62387.4 & & 62387.3 & & 62387.2 & \\
\hline
\end{tabular}


Table A4 Random effect on INTERCEPT only (cont.)

\begin{tabular}{|c|c|c|c|c|c|c|c|c|}
\hline \multirow[b]{2}{*}{ Variable } & \multicolumn{2}{|c|}{$\begin{array}{c}\text { Model } 9 \\
\text { (Random intercept } \\
\text { explained by corruption) }\end{array}$} & \multicolumn{2}{|c|}{$\begin{array}{c}\text { Model } 10 \\
\text { (Random intercept } \\
\text { explained by GDP) } \\
\end{array}$} & \multicolumn{2}{|c|}{$\begin{array}{c}\text { Model } 11 \\
\text { (Random intercept } \\
\text { explained by Education) }\end{array}$} & \multicolumn{2}{|c|}{$\begin{array}{c}\text { Model } 12 \\
\text { (Random intercept } \\
\text { explained by GINI) } \\
\end{array}$} \\
\hline & Estimate & S.E. & Estimate & S.E. & Estimate & S.E. & Estimate & S.E. \\
\hline \multicolumn{9}{|l|}{ Fixed Effect } \\
\hline Intercept & -2.2765 & 0.203 & -1.9601 & 0.1631 & -1.8338 & 0.2249 & 0.006385 & 0.3839 \\
\hline Income & 0.05238 & 0.00445 & 0.05227 & 0.004451 & 0.05233 & 0.004452 & 0.05232 & 0.004452 \\
\hline Education & 0.05968 & 0.004969 & 0.05959 & 0.004969 & 0.05952 & 0.00497 & 0.05951 & 0.004969 \\
\hline Gender & -0.01091 & 0.01961 & -0.01094 & 0.01961 & -0.01088 & 0.01961 & -0.01085 & 0.01961 \\
\hline Age & 0.003286 & 0.000657 & 0.003275 & 0.000657 & 0.003287 & 0.000657 & 0.003275 & 0.000657 \\
\hline Size of Town & -0.02808 & 0.004568 & -0.02795 & 0.004569 & -0.02777 & 0.004571 & -0.02752 & 0.004571 \\
\hline Muslim & 0.1872 & 0.06759 & 0.1869 & 0.06778 & 0.1676 & 0.06791 & 0.1392 & 0.06734 \\
\hline Orthodox & -0.1769 & 0.09042 & -0.1778 & 0.09054 & -0.1931 & 0.09084 & -0.2021 & 0.09057 \\
\hline Protestant & 0.05493 & 0.03846 & 0.05805 & 0.03844 & 0.05995 & 0.03845 & 0.0621 & 0.03843 \\
\hline Catholic & -0.05837 & 0.03075 & -0.05889 & 0.03076 & -0.05728 & 0.03078 & -0.05514 & 0.03078 \\
\hline Oriental Religions & 0.2317 & 0.07183 & 0.2319 & 0.07199 & 0.2124 & 0.07203 & 0.1897 & 0.07164 \\
\hline Corruption & 0.1683 & 0.03287 & & & & & & \\
\hline GDP per Capital & & & 0.000043 & 9.21E-06 & & & & \\
\hline Attainment for Secondary Education & & & & & 0.01649 & 0.006944 & & \\
\hline GINI & & & & & & & -0.03664 & 0.009786 \\
\hline \multicolumn{9}{|l|}{ Random Effect } \\
\hline \multicolumn{9}{|l|}{ Level-one variance } \\
\hline Var (residual for level one) & 1.001 & 0.006042 & 1.0011 & 0.006043 & 1.0012 & 0.006044 & 1.0011 & 0.006043 \\
\hline \multicolumn{9}{|l|}{ Level-two random effects } \\
\hline Intercept Random Effect $\left(\mathrm{U}_{0 . \mathrm{ij}}\right)$ & 0.3348 & 0.07326 & 0.3597 & 0.0786 & 0.4767 & 0.1038 & 0.4048 & 0.08888 \\
\hline $\begin{array}{l}\text { Proportion variance explained by country-level } \\
\text { predicators }\end{array}$ & 0.3641 & & 0.3168 & & 0.0946 & & 0.2311 & \\
\hline Deviance & 62387.5 & & 62387.4 & & 62387.2 & & 62837.6 & \\
\hline
\end{tabular}


Table A4 Random effect on INTERCEPT only (cont.)

\begin{tabular}{|c|c|c|c|c|c|c|c|c|}
\hline & \multicolumn{2}{|c|}{$\begin{array}{c}\text { Model } 13 \\
\text { (Random intercept, } \\
\text { explained by Religious } \\
\text { Fract.) } \\
\end{array}$} & \multicolumn{2}{|c|}{$\begin{array}{c}\text { Model 14 } \\
\text { (Random intercept } \\
\text { explained by } \\
\text { Ethnolinguistic Fract.) } \\
\end{array}$} & \multicolumn{2}{|c|}{$\begin{array}{c}\text { Model } 15 \\
\text { (Random intercept } \\
\text { explained by EFI, Edu, } \\
\text { GINI, Corrup, Fract.) } \\
\end{array}$} & & \\
\hline & Estimate & S.E. & Estimate & S.E. & Estimate & S.E. & & \\
\hline \multicolumn{9}{|l|}{ Fixed Effect } \\
\hline Intercept & -1.6032 & 0.2135 & -1.3763 & 0.1526 & -1.9035 & 0.7355 & & \\
\hline Income & 0.05245 & 0.004452 & 0.05245 & 0.004452 & 0.05219 & 0.004452 & & \\
\hline Education & 0.05954 & 0.00497 & 0.05955 & 0.00497 & 0.05973 & 0.004969 & & \\
\hline Gender & -0.01086 & 0.01961 & -0.01084 & 0.01961 & -0.011 & 0.01962 & & \\
\hline Age & 0.003299 & 0.000657 & 0.003304 & 0.000657 & 0.003258 & 0.000657 & & \\
\hline Size of Town & -0.02791 & 0.004571 & -0.02789 & 0.004571 & -0.02782 & 0.004571 & & \\
\hline Muslim & 0.1623 & 0.068 & 0.155 & 0.06776 & 0.1628 & 0.06754 & & \\
\hline Orthodox & -0.1815 & 0.09095 & -0.1845 & 0.09095 & -0.1777 & 0.09052 & & \\
\hline Protestant & 0.06126 & 0.03844 & 0.06171 & 0.03845 & 0.05586 & 0.03847 & & \\
\hline Catholic & -0.05663 & 0.03078 & -0.05673 & 0.03078 & -0.05658 & 0.03076 & & \\
\hline Oriental Religions & 0.2054 & 0.07199 & 0.2009 & 0.07206 & 0.2165 & 0.07177 & & \\
\hline Economic Freedom Index & & & & & 0.2043 & 0.1257 & & \\
\hline Education Attainment & & & & & -0.01188 & 0.007198 & & \\
\hline GINI & & & & & -0.02914 & 0.00881 & & \\
\hline Corruption & & & & & 0.1194 & 0.05893 & & \\
\hline Religious Fractionalization & 0.597 & 0.4638 & & & -0.1158 & 0.4071 & & \\
\hline Ethnolinguistic Fractionalization & & & 0.008183 & 0.4523 & & & & \\
\hline \multicolumn{9}{|l|}{ Random Effect } \\
\hline \multicolumn{9}{|l|}{ Level-one variance } \\
\hline Var (residual for level one) & 1.0012 & 0.006044 & 1.0012 & 0.006043 & 1.0013 & 0.006044 & & \\
\hline \multicolumn{9}{|l|}{ Level-two random effects } \\
\hline Intercept Random Effect $\left(\mathrm{U}_{0 . \mathrm{ij}}\right)$ & 0.5198 & 0.1129 & 0.5388 & 0.1171 & 0.261 & 0.06016 & & \\
\hline $\begin{array}{l}\text { Proportion variance explained by country-level } \\
\text { predicators }\end{array}$ & 0.0127 & & -0.0234 & & & & & \\
\hline Deviance & 62387.1 & & 62387.2 & & 62387.5 & & & \\
\hline
\end{tabular}


Table A5 Between-group and Within-group Difference for Religions

\begin{tabular}{|c|c|c|c|c|c|c|c|c|}
\hline \multirow[b]{2}{*}{ Variable } & \multicolumn{2}{|c|}{$\begin{array}{c}\text { Model } 16 \\
\text { (Random intercept explained } \\
\text { by Proportion of Muslim } \\
\text { religion) }\end{array}$} & \multicolumn{2}{|c|}{$\begin{array}{c}\text { Model } 17 \\
\text { (Random intercept } \\
\text { explained by Proportion of } \\
\text { Orthodox religion) }\end{array}$} & \multicolumn{2}{|c|}{$\begin{array}{c}\text { Model 18 } \\
\text { (Random intercept } \\
\text { explained by Proportion of } \\
\text { Protestant religion) } \\
\end{array}$} & \multicolumn{2}{|c|}{$\begin{array}{c}\text { Model } 19 \\
\text { (Random intercept } \\
\text { explained by Proportion of } \\
\text { Catholic religion) } \\
\end{array}$} \\
\hline & Estimate & S.E. & Estimate & S.E. & Estimate & S.E. & Estimate & S.E. \\
\hline \multicolumn{9}{|l|}{ Fixed Effect } \\
\hline Intercept & -1.294 & 0.1312 & -1.3265 & 0.1232 & -1.6575 & 0.1116 & -1.1517 & 0.1613 \\
\hline Income Level & 0.05248 & 0.004452 & 0.05251 & 0.004452 & 0.05255 & 0.004449 & 0.05242 & 0.004452 \\
\hline Education & 0.05954 & 0.00497 & 0.0596 & 0.00497 & 0.0596 & 0.004968 & 0.05948 & 0.00497 \\
\hline Gender & -0.01081 & 0.01961 & -0.01079 & 0.01961 & -0.01079 & 0.01961 & -0.01087 & 0.01961 \\
\hline Age & 0.003303 & 0.000657 & 0.00331 & 0.000657 & 0.003318 & 0.000657 & 0.003301 & 0.000657 \\
\hline Size of Town & -0.02795 & 0.004572 & -0.02795 & 0.004571 & -0.02789 & 0.004567 & -0.02777 & 0.004571 \\
\hline Muslim & 0.1699 & 0.06864 & 0.1551 & 0.06771 & 0.1703 & 0.0671 & 0.1386 & 0.06798 \\
\hline Orthodox & -0.1843 & 0.09091 & -0.1656 & 0.09204 & -0.1832 & 0.0902 & -0.1974 & 0.09095 \\
\hline Protestant & 0.0608 & 0.03845 & 0.06149 & 0.03844 & 0.05142 & 0.03851 & 0.06097 & 0.03845 \\
\hline Catholic & -0.05798 & 0.03079 & -0.05752 & 0.03078 & -0.05645 & 0.03074 & -0.05397 & 0.03082 \\
\hline Oriental Religions & 0.2086 & 0.07213 & 0.2003 & 0.07188 & 0.2182 & 0.07149 & 0.1888 & 0.07202 \\
\hline Percentage of Population in Muslim Religion & -0.4981 & 0.3538 & & & & & & \\
\hline Percentage of Population in Orthodox Religion & & & -0.6976 & 0.5083 & & & & \\
\hline Percentage of Population in Protestant Religion & & & & & 1.898 & 0.3504 & & \\
\hline Percentage of Population in Catholic Religion & & & & & & & -0.5505 & 0.2778 \\
\hline \multicolumn{9}{|l|}{ Random Effect } \\
\hline \multicolumn{9}{|l|}{ Level-one variance } \\
\hline Var (residual for level one) & 1.0012 & 0.0060 & 1.0012 & 0.006043 & 1.0005 & 0.006039 & 1.0011 & 0.006043 \\
\hline \multicolumn{9}{|l|}{ Level-two random effects } \\
\hline Intercept variance Effect $\left(\mathrm{U}_{0 . \mathrm{ij}}\right)$ & 0.5157 & 0.112 & 0.5166 & 0.1123 & 0.3201 & 0.07009 & 0.4914 & 0.1075 \\
\hline Deviance & 62387.1 & & 62387.1 & & 62387.5 & & 62387.5 & \\
\hline
\end{tabular}


Table A6 Random effect on INTERCEPT and SLOPE

\begin{tabular}{|c|c|c|c|c|c|c|c|c|}
\hline \multirow[b]{2}{*}{ Variable } & \multicolumn{2}{|c|}{$\begin{array}{c}\text { Model } 20 \\
\text { (Intercept and Muslim) }\end{array}$} & \multicolumn{2}{|c|}{$\begin{array}{c}\text { Model } 21 \\
\text { (Intercept and Orthodox) }\end{array}$} & \multicolumn{2}{|c|}{$\begin{array}{c}\text { Model } 22 \\
\text { (Intercept and Protestant) }\end{array}$} & \multicolumn{2}{|c|}{$\begin{array}{c}\text { Model } 23 \\
\text { (Intercept and Catholic) }\end{array}$} \\
\hline & Estimate & S.E. & Estimate & S.E. & Estimate & S.E. & Estimate & S.E. \\
\hline \multicolumn{9}{|l|}{ Fixed Effect } \\
\hline Intercept & -0.8727 & 0.08957 & -0.8574 & 0.09391 & -0.881 & 0.0952 & -0.8755 & 0.09583 \\
\hline Income Level & 0.05167 & 0.004456 & 0.05215 & 0.004456 & 0.05189 & 0.00446 & 0.05139 & 0.004458 \\
\hline Education & 0.05964 & 0.004974 & 0.05982 & 0.004973 & 0.05938 & 0.004976 & 0.05943 & 0.004973 \\
\hline Gender & -0.01174 & 0.01962 & -0.01061 & 0.01962 & -0.01137 & 0.01962 & -0.01182 & 0.01962 \\
\hline Age & 0.003227 & 0.000657 & 0.003263 & 0.000657 & 0.003233 & 0.000658 & 0.003296 & 0.000657 \\
\hline Size of Town & -0.02677 & 0.004583 & -0.02758 & 0.004579 & -0.0274 & 0.004581 & -0.02731 & 0.004586 \\
\hline Muslim & -0.05103 & 0.1309 & 0.1977 & 0.06873 & 0.1805 & 0.06772 & 0.1745 & 0.0709 \\
\hline Orthodox & -0.19 & 0.09284 & -0.09139 & 0.2406 & -0.1508 & 0.09082 & -0.1421 & 0.09246 \\
\hline Protestant & 0.053 & 0.03847 & 0.06338 & 0.03852 & 0.1692 & 0.1022 & 0.04266 & 0.04067 \\
\hline Catholic & -0.06116 & 0.03085 & -0.06309 & 0.03078 & -0.03968 & 0.03128 & -0.06217 & 0.05679 \\
\hline Oriental Religions & 0.2949 & 0.08221 & 0.2387 & 0.07225 & 0.2258 & 0.07243 & 0.2251 & 0.07504 \\
\hline Economic Freedom Index & 0.4223 & 0.07885 & 0.4067 & 0.08275 & 0.4235 & 0.08399 & 0.4378 & 0.08511 \\
\hline $\begin{array}{l}\text { Economic Freedom X Random Slope } \\
\text { Variable }\end{array}$ & -0.2183 & 0.1234 & 0.05009 & 0.1894 & -0.04351 & 0.08295 & -0.04224 & 0.05007 \\
\hline \multicolumn{9}{|l|}{ Random Effect } \\
\hline \multicolumn{9}{|l|}{ Level-one variance } \\
\hline Var (residual for level one) & 1.0009 & 0.006043 & 1.0007 & 0.006042 & 1.0004 & 0.006041 & 1.0002 & 0.00604 \\
\hline \multicolumn{9}{|l|}{ Level-two random effects } \\
\hline Intercept variance Effect $\left(\mathrm{U}_{0 . \mathrm{ij}}\right)$ & 0.3331 & 0.07473 & 0.3728 & 0.08129 & 0.3841 & 0.08523 & 0.3865 & 0.08494 \\
\hline Slope variance for Muslim & 0.1787 & 0.1294 & & & & & & \\
\hline Intercept-Muslim slope covariance & -0.0124 & 0.07873 & & & & & & \\
\hline Slope variance for Orthodox & & & 0.8083 & 0.4164 & & & & \\
\hline Intercept-Orthodox slope covariance & & & 0.04736 & 0.1763 & & & & \\
\hline Slope variance for Protestant & & & & & 0.1808 & 0.08655 & & \\
\hline Intercept-Protestant slope covariance & & & & & -0.04224 & 0.0603 & & \\
\hline Slope variance for Catholic & & & & & & & 0.06802 & 0.02881 \\
\hline Intercept-Catholic slope covariance & & & & & & & -0.05835 & 0.04464 \\
\hline Deviance & 62347.1 & & 62315.1 & & 62281.1 & & 62297.2 & \\
\hline Reduction in Deviance (Model 3) & 40.2 & & 72.2 & & 106.2 & & 90.1 & \\
\hline
\end{tabular}


Table A6 Random effect on INTERCEPT and SLOPE (cont.)

\begin{tabular}{|c|c|c|c|c|c|c|c|c|}
\hline \multirow[b]{2}{*}{ Variable } & \multicolumn{2}{|c|}{$\begin{array}{c}\text { Model } 24 \\
\text { (Intercept and Income level) }\end{array}$} & \multicolumn{2}{|c|}{$\begin{array}{c}\text { Model } 25 \\
\text { (Intercept and Education) }\end{array}$} & \multicolumn{2}{|c|}{$\begin{array}{c}\text { Model } 26 \\
\text { (Intercept and town) }\end{array}$} & & \\
\hline & Estimate & S.E. & Estimate & S.E. & Estimate & S.E. & & \\
\hline \multicolumn{9}{|l|}{ Fixed Effect } \\
\hline Intercept & -0.8882 & 0.09546 & -0.8748 & 0.09698 & -0.8787 & 0.09509 & & \\
\hline Income Level & 0.0459 & 0.01075 & 0.04814 & 0.004552 & 0.05358 & 0.00449 & & \\
\hline Education & 0.06699 & 0.005033 & 0.09193 & 0.01655 & 0.06251 & 0.005018 & & \\
\hline Gender & -0.00244 & 0.01967 & -0.03646 & 0.01982 & -0.0098 & 0.01965 & & \\
\hline Age & 0.004194 & 0.000664 & 0.003915 & 0.000667 & 0.003437 & 0.000659 & & \\
\hline Size of Town & -0.02224 & 0.00466 & -0.02316 & 0.004715 & -0.01653 & 0.0105 & & \\
\hline Muslim & 0.1972 & 0.06767 & 0.1455 & 0.06818 & 0.155 & 0.06819 & & \\
\hline Orthodox & -0.1715 & 0.09052 & -0.1637 & 0.09072 & -0.1772 & 0.09084 & & \\
\hline Protestant & 0.0654 & 0.03858 & 0.08699 & 0.039 & 0.06908 & 0.03854 & & \\
\hline Catholic & -0.05271 & 0.03088 & -0.03301 & 0.03119 & -0.05225 & 0.03092 & & \\
\hline Oriental Religions & 0.2455 & 0.07196 & 0.2156 & 0.07212 & 0.1998 & 0.07284 & & \\
\hline Economic Freedom Index & 0.4244 & 0.08412 & 0.4177 & 0.08549 & 0.4215 & 0.08378 & & \\
\hline $\begin{array}{l}\text { Economic Freedom X Random Slope } \\
\text { Variable }\end{array}$ & 0.03561 & 0.009747 & 0.07537 & 0.01487 & 0.0207 & 0.009594 & & \\
\hline \multicolumn{9}{|l|}{ Random Effect } \\
\hline \multicolumn{9}{|l|}{ Level-one variance } \\
\hline Var (residual for level one) & 0.9975 & 0.006023 & 0.9978 & 0.006025 & 1.0001 & 0.00604 & & \\
\hline \multicolumn{9}{|l|}{ Level-two random effects } \\
\hline Intercept variance Effect $\left(\mathrm{U}_{0 . \mathrm{ij}}\right)$ & 0.3869 & 0.08421 & 0.3999 & 0.08702 & 0.3836 & 0.08352 & & \\
\hline Slope variance for Income & 0.004083 & 0.001091 & & & & & & \\
\hline Intercept-Income slope covariance & 0.0135 & 0.007308 & & & & & & \\
\hline Slope variance for Education & & & 0.01104 & 0.002589 & & & & \\
\hline Intercept-Education slope covariance & & & 0.01767 & 0.01115 & & & & \\
\hline Slope variance for Town & & & & & 0.003571 & 0.001058 & & \\
\hline Intercept-Town slope covariance & & & & & -0.00726 & 0.007107 & & \\
\hline Deviance & 62032.3 & & 61381.3 & & 62159.8 & & & \\
\hline Reduction in Deviance (Model 3) & 355 & & 1006 & & 227.5 & & & \\
\hline
\end{tabular}


Table A7 Random Intercept and Random Slope for Each Country

\begin{tabular}{|c|c|c|c|c|c|c|c|c|c|c|c|c|c|c|}
\hline \multirow{2}{*}{ Country_Year } & \multicolumn{2}{|c|}{ Model 20} & \multicolumn{2}{|c|}{ Model 21} & \multicolumn{2}{|c|}{ Model 22} & \multicolumn{2}{|c|}{ Model 23} & \multicolumn{2}{|c|}{ Model 24} & \multicolumn{2}{|c|}{ Model 25} & \multicolumn{2}{|c|}{ Model 26} \\
\hline & Intercept & Muslim & Intercept & Orthodox & Intercept & Protestant & Intercept & Catholic & Intercept & Income & Intercept & Education & Intercept & Size of town \\
\hline Albania (2002) & -1.0690 & -0.0608 & -1.2538 & 0.0214 & -1.2169 & 0.2040 & -1.2426 & 0.2216 & -1.2247 & -0.0002 & -1.1807 & -0.0283 & -1.2001 & 0.0161 \\
\hline Australia (1995) & -0.3473 & -0.4647 & -0.3556 & -0.1923 & -0.2485 & -0.1688 & -0.3478 & -0.0532 & -0.3670 & 0.0783 & -0.3650 & 0.1308 & -0.3618 & -0.0018 \\
\hline Austria (1999) & -0.5774 & -0.2825 & -0.5721 & -1.2398 & -0.6102 & 0.2903 & -0.6169 & -0.0132 & -0.6020 & 0.1045 & -0.6369 & 0.2679 & -0.5901 & -0.0059 \\
\hline Bangladesh (1996) & -1.6838 & 0.2413 & -1.6402 & -0.1889 & -1.6244 & 0.2473 & -1.6166 & -0.1217 & -1.6417 & -0.0440 & -1.5913 & -0.1111 & -1.6034 & -0.0750 \\
\hline Bangladesh (2002) & -1.2735 & 0.0764 & -1.3795 & -0.2687 & -1.3640 & 0.4721 & -1.3569 & -0.0324 & -1.3828 & -0.0474 & -1.3638 & -0.1759 & -1.3551 & -0.1759 \\
\hline Belgium (1999) & -0.7337 & -0.2010 & -0.7402 & 0.0940 & -0.7508 & -0.1069 & -0.7280 & -0.0815 & -0.7715 & 0.1378 & -0.7569 & 0.2628 & -0.7404 & 0.0207 \\
\hline Brazil (1991) & -2.5798 & 0.4675 & -2.5519 & -0.9371 & -2.5965 & 0.0475 & -2.6134 & -0.0126 & -2.5834 & -0.0104 & -2.5800 & 0.0134 & -2.5959 & -0.0089 \\
\hline Bulgaria (1999) & -0.9538 & 0.2995 & -1.0522 & 0.0005 & -0.9627 & 0.0119 & -0.9678 & -0.0733 & -0.9507 & 0.0169 & -0.9419 & 0.0442 & -0.9551 & -0.0543 \\
\hline Canada (2000) & -0.4114 & -0.0340 & -0.4130 & -0.5600 & -0.4945 & 0.4624 & -0.2670 & -0.4514 & -0.4661 & 0.1321 & -0.4613 & 0.2440 & -0.4256 & -0.0151 \\
\hline Chile (1996) & -1.2174 & -0.2008 & -1.2184 & -0.1385 & -1.2660 & 1.0277 & -1.1807 & -0.1130 & -1.2338 & -0.0514 & -1.2275 & 0.0543 & -1.2289 & 0.0537 \\
\hline Chile (2000) & -1.1697 & -0.2063 & -1.1704 & -0.1325 & -1.1809 & -0.0026 & -1.1865 & -0.0298 & -1.1829 & 0.0547 & -1.1731 & 0.0480 & $\mid-1.1773$ & -0.0202 \\
\hline Denmark (1999) & 0.7689 & -0.2416 & 0.7601 & 0.1125 & 0.7002 & 0.1335 & 0.7809 & -0.3094 & 0.7997 & 0.1724 & 0.8187 & 0.2700 & 0.7550 & 0.0070 \\
\hline Dominican Republic (1996) & -1.0008 & 0.0503 & -0.9993 & -0.1087 & -1.0162 & 0.1920 & -1.0233 & -0.0233 & -1.0089 & 0.0469 & -1.0053 & 0.1039 & -1.0047 & -0.0738 \\
\hline Egypt (2000) & -0.9041 & 0.4630 & -0.6538 & -0.0655 & -0.6373 & 0.1424 & -0.6313 & -0.0991 & -0.6576 & -0.0543 & -0.6030 & -0.1366 & -0.6146 & -0.0727 \\
\hline Finland (2000) & 0.2420 & -0.3043 & 0.2371 & -0.6444 & 0.1809 & 0.1285 & 0.2514 & -0.2073 & 0.2247 & 0.0583 & 0.2404 & 0.1536 & 0.2292 & -0.0174 \\
\hline France (1999) & -1.1394 & -0.1076 & -1.1430 & 0.1335 & -1.1506 & 0.0268 & -1.0851 & -0.1659 & -1.1606 & 0.1167 & -1.2359 & 0.2651 & -1.1675 & 0.0723 \\
\hline Germany (1999) & -0.6602 & -0.7042 & -0.6887 & 1.4270 & -0.6709 & 0.0281 & -0.6824 & -0.0205 & -0.7000 & 0.0726 & -0.6876 & 0.1636 & -0.6838 & -0.0298 \\
\hline Great Britain (1999) & \begin{tabular}{|c|c|}
-0.7888 \\
\end{tabular} & -0.2921 & -0.7966 & -0.0106 & -0.5727 & -0.3698 & -0.8097 & 0.1132 & -0.8086 & 0.1127 & -0.8109 & 0.1889 & -0.8075 & 0.0680 \\
\hline Greece (1999) & -1.0176 & -0.1006 & -0.7010 & -0.5365 & -1.0553 & 0.1892 & -1.0644 & 0.0090 & -1.0486 & 0.1023 & -1.0458 & 0.1731 & -1.0341 & 0.0253 \\
\hline Hungary (1999) & -1.2186 & -0.0508 & -1.2216 & 0.2554 & -1.2476 & 0.1760 & -1.0898 & -0.4053 & -1.2265 & 0.1020 & -1.2094 & 0.1820 & -1.2362 & 0.0728 \\
\hline India (1990) & -0.8869 & 0.3208 & -0.8324 & 0.5030 & -0.8229 & 0.4646 & -0.8229 & 0.2204 & -0.8376 & -0.0037 & -0.7920 & 0.0202 & -0.7954 & -0.0467 \\
\hline India (1995) & -0.6989 & 0.1936 & -0.6556 & 0.3470 & -0.6429 & -0.0131 & -0.6337 & -0.3126 & -0.6650 & 0.0649 & -0.6200 & -0.0276 & -0.6232 & -0.0991 \\
\hline India (2001) & -0.6451 & 0.5856 & -0.5617 & -0.0530 & -0.5507 & 0.1314 & -0.5481 & -0.0882 & -0.5727 & -0.0846 & -0.5299 & -0.0552 & -0.5302 & -0.0929 \\
\hline Indonesia (2001) & -0.4665 & 0.5712 & -0.1181 & 0.0044 & -0.1032 & 0.0802 & -0.0823 & -0.2954 & -0.1184 & 0.1197 & -0.0600 & -0.0109 & -0.0801 & -0.0419 \\
\hline Italy (1999) & -0.6071 & -0.1453 & -0.6062 & 0.3221 & -0.6248 & 0.2092 & -0.5981 & -0.0723 & -0.6341 & 0.1164 & -0.6615 & 0.2493 & -0.6227 & 0.0722 \\
\hline Jordan (2001) & -1.0909 & 0.1392 & -1.1464 & -0.1282 & -1.1310 & 0.1970 & \begin{tabular}{|c|}
-1.1222 \\
\end{tabular} & -0.0870 & -1.1482 & -0.0061 & -1.0829 & 0.0437 & -1.1172 & -0.0058 \\
\hline Mexico (1996) & -0.6071 & -0.1805 & -0.6074 & -0.0592 & -0.6549 & 0.6454 & -0.7327 & 0.1411 & -0.6183 & -0.0639 & -0.6140 & -0.0585 & -0.6310 & -0.1473 \\
\hline Mexico (2000) & -1.1666 & 0.0379 & -1.1658 & -0.1300 & -1.1780 & -0.1692 & -1.3735 & 0.2170 & -1.1974 & -0.0213 & -1.2247 & -0.0352 & -1.1847 & -0.0727 \\
\hline Netherlands (1999) & 0.4435 & -0.4365 & 0.4380 & 0.0710 & 0.4676 & -0.2616 & $\begin{array}{l}0.4315 \\
\end{array}$ & -0.0276 & 0.4614 & 0.1564 & 0.5119 & 0.3588 & 0.4356 & -0.0010 \\
\hline Norway (1996) & 0.6848 & -0.6002 & 0.6679 & 0.3900 & 0.8224 & -0.1163 & 0.6945 & -0.3578 & 0.6851 & 0.1189 & 0.7355 & 0.2937 & 0.6690 & 0.0354 \\
\hline Pakistan (2001) & -0.7866 & 0.1767 & -0.7863 & -0.0806 & -0.7862 & 0.1553 & -0.7860 & -0.1029 & -0.7911 & 0.0523 & -0.7724 & -0.0158 & -0.7860 & -0.0576 \\
\hline Philippines (2001) & -2.3209 & 0.2352 & -2.3230 & -0.2776 & -2.3384 & 0.0753 & -2.2050 & -0.2238 & -2.3329 & 0.0175 & -2.3335 & 0.0032 & -2.3290 & -0.0234 \\
\hline Poland (1999) & -1.4075 & 0.0285 & -1.4067 & -0.3730 & -1.4313 & 0.5066 & -1.2642 & -0.2139 & -1.4231 & 0.0713 & -1.4239 & 0.0854 & -1.4334 & 0.0244 \\
\hline Romania (1999) & -2.0293 & 0.3574 & -1.3099 & -1.1428 & -2.1035 & 1.0180 & -2.1022 & 0.2831 & -2.0379 & 0.0168 & -2.0287 & 0.0096 & -2.0435 & -0.0691 \\
\hline South Africa (1996) & -1.5656 & -0.2015 & -1.6057 & 1.1043 & -1.3499 & -0.3575 & -1.5914 & 0.1464 & -1.6604 & -0.0821 & -1.6376 & -0.0677 & -1.6232 & -0.0733 \\
\hline Spain (1995) & -0.7619 & 0.1207 & -0.7608 & -0.0796 & -0.7800 & 0.1172 & -0.8394 & 0.0325 & -0.7750 & 0.0583 & -0.7738 & 0.0609 & \begin{tabular}{|c|}
-0.7720 \\
\end{tabular} & 0.0083 \\
\hline Spain (2000) & -0.6522 & -0.2625 & -0.6520 & -0.0664 & -0.6702 & 0.0577 & -0.8044 & 0.1246 & -0.6674 & 0.0824 & -0.6698 & 0.0955 & -0.6631 & 0.0247 \\
\hline Sweden (1999) & 0.6168 & -0.3985 & 0.6051 & 0.5079 & 0.5951 & 0.0840 & 0.6280 & -0.2583 & 0.6155 & 0.1009 & 0.6654 & 0.3110 & 0.6072 & -0.0106 \\
\hline Switzerland (1989) & -0.1788 & -0.3108 & -0.1819 & -0.0074 & -0.2891 & 0.3143 & -0.0578 & -0.2871 & -0.1936 & 0.0911 & -0.1996 & 0.2236 & -0.1896 & 0.0115 \\
\hline Switzerland (1996) & -0.3747 & -0.3869 & -0.3802 & -0.9357 & -0.5687 & 0.4058 & -0.2381 & -0.3635 & -0.3995 & 0.0681 & -0.4050 & 0.1343 & -0.4008 & 0.0208 \\
\hline Turkey (2001) & -2.1802 & -0.4160 & -2.7590 & -0.3750 & -2.7453 & 0.3700 & -2.7400 & 0.1866 & -2.7651 & -0.0708 & -2.6947 & -0.0465 & -2.7318 & 0.0173 \\
\hline United States (1995) & -0.5428 & -0.5343 & -0.5484 & -0.4825 & -0.5390 & 0.0198 & -0.6012 & 0.1805 & -0.5657 & 0.1187 & -0.5874 & 0.1788 & -0.5504 & 0.0293 \\
\hline United States (1999) & -0.5448 & -0.3473 & -0.5524 & 0.3207 & -0.6370 & 0.3458 & -0.5828 & 0.1001 & -0.5633 & 0.0811 & -0.5701 & 0.1594 & -0.5534 & 0.0035 \\
\hline Uruguay (1996) & -1.2266 & 0.0716 & -1.2263 & -0.1374 & -1.2399 & 0.3349 & -1.1864 & -0.1602 & -1.2375 & 0.0150 & -1.2225 & 0.0716 & -1.2328 & -0.0539 \\
\hline Venezuela (1996) & -1.8375 & 0.4805 & -1.8357 & -0.2859 & -1.8602 & 0.1392 & -1.7743 & -0.1338 & -1.8437 & 0.0156 & -1.8417 & 0.0347 & -1.8548 & 0.0272 \\
\hline Venezuela (2000) & -1.5754 & 0.2077 & -1.5754 & -0.1808 & -1.5788 & -0.1023 & -1.8616 & 0.3615 & -1.5787 & -0.0221 & -1.5902 & 0.0989 & -1.5854 & -0.0248 \\
\hline
\end{tabular}


Table A8 Country Clusters based on Religion Characteristics in Each Country

\begin{tabular}{|c|c|c|c|c|c|c|c|c|c|}
\hline \multirow[b]{2}{*}{ Country } & \multirow[b]{2}{*}{ Cluster } & \multicolumn{4}{|c|}{ Religious Belief } & \multicolumn{4}{|c|}{$\begin{array}{c}\text { Proportion of Population belongs to } \\
\text { Religious Denomination }\end{array}$} \\
\hline & & Muslim & Orthodox & Protestant & Catholic & $\begin{array}{l}\text { Muslim } \\
\text { Prop. }\end{array}$ & \begin{tabular}{|c|} 
Orthodox \\
Prop.
\end{tabular} & $\begin{array}{l}\text { Protestant } \\
\text { Prop. }\end{array}$ & $\begin{array}{c}\text { Catholics } \\
\text { Prop. }\end{array}$ \\
\hline Albania (2002) & 1 & -0.0608 & 0.0214 & 0.2040 & 0.2216 & 0.4327 & 0.1907 & 0.0122 & 0.1628 \\
\hline Bangladesh (1996) & 1 & 0.2413 & -0.1889 & 0.2473 & -0.1217 & 0.8707 & 0.0000 & 0.0014 & 0.0018 \\
\hline Bangladesh (2002) & 1 & 0.0764 & -0.2687 & 0.4721 & -0.0324 & 0.8707 & 0.0000 & 0.0014 & 0.0018 \\
\hline Egypt (2000) & 1 & 0.4630 & -0.0655 & 0.1424 & -0.0991 & 0.8481 & 0.1332 & 0.0073 & 0.0034 \\
\hline India (1990) & 1 & 0.3208 & 0.5030 & 0.4646 & 0.2204 & 0.1223 & 0.0030 & 0.0178 & 0.0166 \\
\hline India (1995) & 1 & 0.1936 & 0.3470 & -0.0131 & -0.3126 & 0.1223 & 0.0030 & 0.0178 & 0.0166 \\
\hline India (2001) & 1 & 0.5856 & -0.0530 & 0.1314 & -0.0882 & 0.1223 & 0.0030 & 0.0178 & 0.0166 \\
\hline Indonesia (2001) & 1 & 0.5712 & 0.0044 & 0.0802 & -0.2954 & 0.5397 & 0.0000 & 0.0633 & 0.0311 \\
\hline Jordan (2001) & 1 & 0.1392 & -0.1282 & 0.1970 & -0.0870 & 0.9383 & 0.0169 & 0.0023 & 0.0072 \\
\hline Pakistan (2001) & 1 & 0.1767 & -0.0806 & 0.1553 & -0.1029 & 0.9591 & 0.0000 & 0.0123 & 0.0090 \\
\hline Turkey (2001) & 1 & -0.4160 & -0.3750 & 0.3700 & 0.1866 & 0.9730 & 0.0020 & 0.0004 & 0.0004 \\
\hline Average & 1 & 0.2083 & -0.0258 & 0.2228 & -0.0464 & 0.6181 & 0.0320 & 0.0140 & 0.0243 \\
\hline Australia (1995) & 2 & -0.4647 & -0.1923 & -0.1688 & -0.0532 & 0.0165 & 0.0385 & 0.1274 & 0.2688 \\
\hline Belgium (1999) & 2 & -0.2010 & 0.0940 & -0.1069 & -0.0815 & 0.0359 & 0.0047 & 0.0139 & 0.7587 \\
\hline Chile (1996) & 2 & -0.2008 & -0.1385 & 1.0277 & -0.1130 & 0.0043 & 0.0244 & 0.0297 & 0.7640 \\
\hline Chile (2000) & 2 & -0.2063 & -0.1325 & -0.0026 & -0.0298 & 0.0043 & 0.0244 & 0.0297 & 0.7640 \\
\hline Dominican Republic & 2 & 0.0503 & -0.1087 & 0.1920 & -0.0233 & 0.0002 & 0.0000 & 0.0659 & 0.8891 \\
\hline France (1999) & 2 & -0.1076 & 0.1335 & 0.0268 & -0.1659 & 0.0821 & 0.0121 & 0.0238 & 0.7622 \\
\hline Great Britain (1999) & 2 & -0.2921 & -0.0106 & -0.3698 & 0.1132 & 0.0224 & 0.0063 & 0.0672 & 0.0958 \\
\hline Hungary (1999) & 2 & -0.0508 & 0.2554 & 0.1760 & -0.4053 & 0.0024 & 0.0096 & 0.2412 & 0.6311 \\
\hline Italy (1999) & 2 & -0.1453 & 0.3221 & 0.2092 & -0.0723 & 0.0120 & 0.0022 & 0.0058 & 0.9659 \\
\hline Mexico (1996) & 2 & -0.1805 & -0.0592 & 0.6454 & 0.1411 & 0.0020 & 0.0010 & 0.0417 & 0.9325 \\
\hline Mexico (2000) & 2 & 0.0379 & -0.1300 & -0.1692 & 0.2170 & 0.0020 & 0.0010 & 0.0417 & 0.9325 \\
\hline Netherlands (1999) & 2 & -0.4365 & 0.0710 & -0.2616 & -0.0276 & 0.0493 & 0.0006 & 0.2133 & 0.3191 \\
\hline Philippines (2001) & 2 & 0.2352 & -0.2776 & 0.0753 & -0.2238 & 0.0643 & 0.0000 & 0.0628 & 0.8242 \\
\hline Poland (1999) & 2 & 0.0285 & -0.3730 & 0.5066 & -0.2139 & 0.0001 & 0.0234 & 0.0037 & 0.9165 \\
\hline Spain (1995) & 2 & 0.1207 & -0.0796 & 0.1172 & 0.0325 & 0.0104 & 0.0001 & 0.0025 & 0.9342 \\
\hline Spain (2000) & 2 & -0.2625 & -0.0664 & 0.0577 & 0.1246 & 0.0104 & 0.0001 & 0.0025 & 0.9342 \\
\hline Switzerland (1989) & 2 & -0.3108 & -0.0074 & 0.3143 & -0.2871 & 0.0430 & 0.0143 & 0.3464 & 0.4385 \\
\hline United States (1995) & 2 & -0.5343 & -0.4825 & 0.0198 & 0.1805 & 0.0155 & 0.0200 & 0.2043 & 0.2196 \\
\hline United States (1999) & 2 & -0.3473 & 0.3207 & 0.3458 & 0.1001 & 0.0155 & 0.0200 & 0.2043 & 0.2196 \\
\hline Uruguay (1996) & 2 & 0.0716 & -0.1374 & 0.3349 & -0.1602 & 0.0001 & 0.0084 & 0.0280 & 0.6930 \\
\hline Venezuela (1996) & 2 & 0.4805 & -0.2859 & 0.1392 & -0.1338 & 0.0033 & 0.0010 & 0.0441 & 0.9385 \\
\hline Venezuela (2000) & 2 & 0.2077 & -0.1808 & -0.1023 & 0.3615 & 0.0033 & 0.0010 & 0.0441 & 0.9385 \\
\hline Average & 2 & -0.1140 & -0.0666 & 0.1367 & -0.0327 & 0.0182 & 0.0097 & 0.0838 & 0.6882 \\
\hline Austria (1999) & 3 & -0.2825 & -1.2398 & 0.2903 & -0.0132 & 0.0295 & 0.0124 & 0.0447 & 0.7106 \\
\hline Brazil (1991) & 3 & 0.4675 & -0.9371 & 0.0475 & -0.0126 & 0.0010 & 0.0007 & 0.1660 & 0.8530 \\
\hline Canada (2000) & 3 & -0.0340 & -0.5600 & 0.4624 & -0.4514 & 0.0168 & 0.0216 & 0.1450 & 0.4379 \\
\hline Switzerland (1996) & 3 & -0.3869 & -0.9357 & 0.4058 & -0.3635 & 0.0430 & 0.0143 & 0.3464 & 0.4385 \\
\hline Average & 3 & -0.0590 & -0.9181 & 0.3015 & -0.2102 & 0.0226 & 0.0123 & 0.1756 & 0.6100 \\
\hline Romania (1999) & 4 & 0.3574 & -1.1428 & 1.0180 & 0.2831 & 0.0073 & 0.8774 & 0.0643 & 0.0855 \\
\hline Bulgaria (1999) & 5 & 0.2995 & 0.0005 & 0.0119 & -0.0733 & 0.1177 & 0.8092 & 0.0141 & 0.0105 \\
\hline Greece (1999) & 5 & -0.1006 & -0.5365 & 0.1892 & 0.0090 & 0.0465 & 0.9115 & 0.0019 & 0.0050 \\
\hline Average & 5 & 0.0994 & -0.2680 & 0.1006 & -0.0322 & 0.0821 & 0.8604 & 0.0080 & 0.0078 \\
\hline Germany (1999) & 6 & -0.7042 & 1.4270 & 0.0281 & -0.0205 & 0.0447 & 0.0123 & 0.3506 & 0.3260 \\
\hline South Africa (1996) & 6 & -0.2015 & 1.1043 & -0.3575 & 0.1464 & 0.0243 & 0.0023 & 0.2124 & 0.0700 \\
\hline Average & 6 & -0.4529 & 1.2657 & -0.1647 & 0.0630 & 0.0345 & 0.0073 & 0.2815 & 0.1980 \\
\hline Denmark (1999) & 7 & -0.2416 & 0.1125 & 0.1335 & -0.3094 & 0.0212 & 0.0019 & 0.8374 & 0.0066 \\
\hline Finland (2000) & 7 & -0.3043 & -0.6444 & 0.1285 & -0.2073 & 0.0030 & 0.0110 & 0.8528 & 0.0017 \\
\hline Norway (1996) & 7 & -0.6002 & 0.3900 & -0.1163 & -0.3578 & 0.0193 & 0.0007 & 0.8985 & 0.0142 \\
\hline Sweden (1999) & 7 & -0.3985 & 0.5079 & 0.0840 & -0.2583 & 0.0201 & 0.0162 & 0.8776 & 0.0115 \\
\hline Average & 7 & -0.3862 & 0.0915 & 0.0574 & -0.2832 & 0.0159 & 0.0074 & 0.8666 & 0.0085 \\
\hline Grand Average & & -0.0510 & -0.0914 & 0.1692 & -0.0622 & 0.1651 & 0.0708 & 0.1480 & 0.3995 \\
\hline
\end{tabular}


Table A9 Summary of the Findings from Empirical or Case Studies

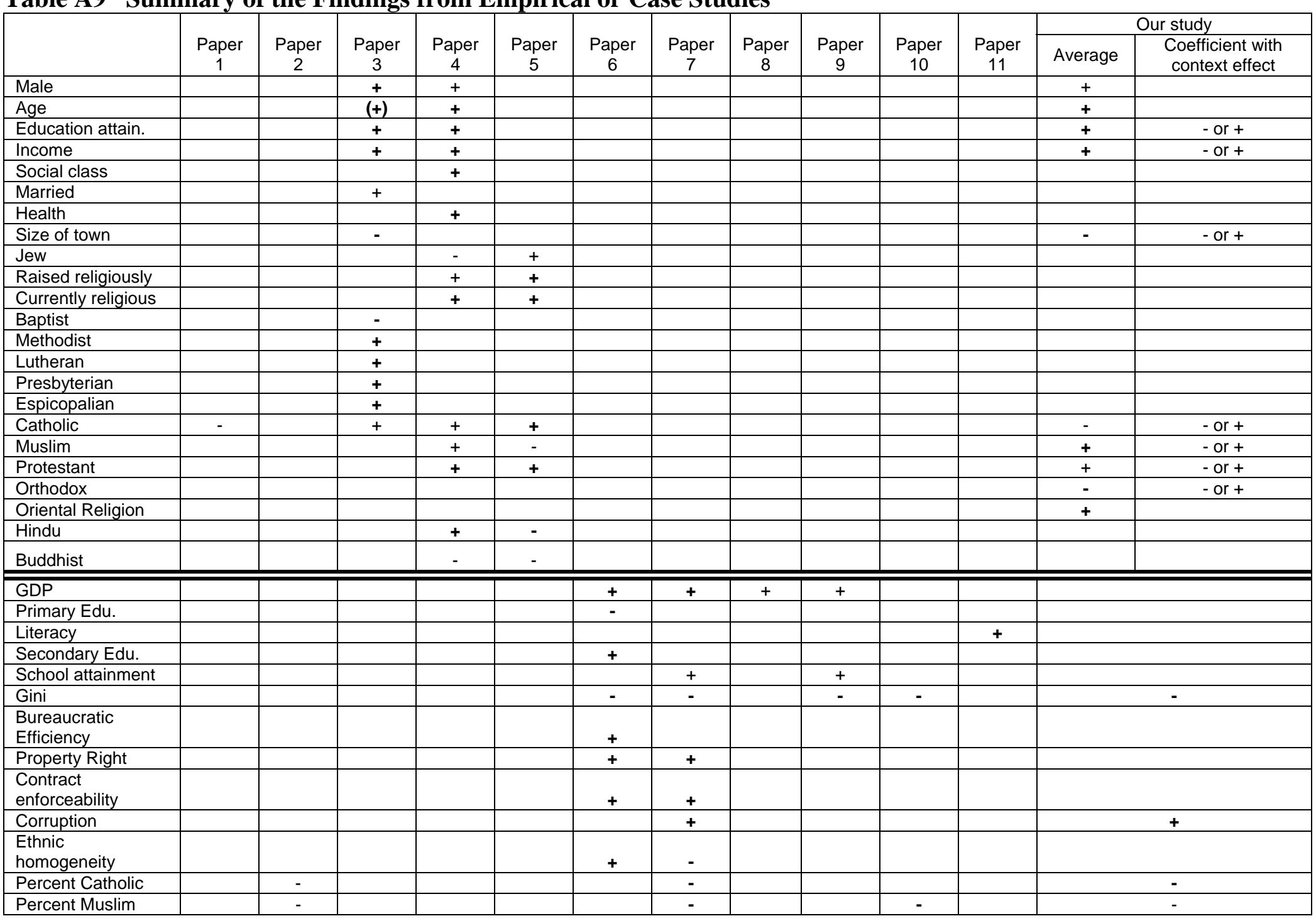




\begin{tabular}{|c|c|c|c|c|c|c|c|c|c|c|c|c|}
\hline Percent Orthodox & & - & & & & & + & & & & & - \\
\hline Percent Protestant & & & & & & & & & & + & & + \\
\hline $\begin{array}{l}\text { Percent } \\
\text { hierarchical } \\
\text { religions }\end{array}$ & & & & & & & & & - & & & \\
\hline EFI & & & & & & & & & + & & + & + \\
\hline EFI1 & & & & & & & & & $+/-$ & & & + \\
\hline EFI2 & & & & & & & & & + & & & + \\
\hline EFI3 & & & & & & & & & + & & & + \\
\hline EFI4 & & & & & & & & & $+/-$ & & & + \\
\hline EFI5 & & & & & & & & & + & & & + \\
\hline $\begin{array}{l}\text { Religious } \\
\text { fractionalization }\end{array}$ & & & & & & & & & - & & & $+/-$ \\
\hline $\begin{array}{l}\text { Ethnolinguistic } \\
\text { Fractionalization }\end{array}$ & & & & & & & & & & & & $+/-$ \\
\hline Data & survey & WVS & GSS & WVS & WVS & WVS & WVS & WVS & WVS & WVS & WVS & WVS \\
\hline Individual level & & & Yes & Yes & Yes & & & & & & & \\
\hline Group level & & Yes & & & & Yes & Yes & Yes & Yes & Yes & Yes & \\
\hline Multi-level & & & & & & & & & & & & Yes \\
\hline Region & Italy & World & US & World & World & World & World & $\begin{array}{c}\text { Europ } \\
\mathrm{e}\end{array}$ & World & World & $\begin{array}{c}\text { Europ } \\
\mathrm{e}\end{array}$ & World \\
\hline
\end{tabular}

Paper 1: Putnam, R.; Leonardi, R.; and Nanetti, R.Y. 1993. Making democracy work. Princeton, New Jersey: Princeton University Press. Authors argue that “ "the Italian Church retains much of the heritage of the Counter-Reformation, including an emphasis on the ecclesiastical hierarchy and the traditional virtues of obedience and acceptance of one's station in life. Vertical bonds of authority are more characteristic of the Italian Church than horizontal bonds of fellowship” (p. 107). The analysis is only based on observations, no model. It is a case study

Paper 2: La Porta, R., F. Lopez-de-Silanes, A. Shleifer, and R. Vishny (1997), Trust in Large Organizations, American Economic Review Papers and Proceedings, Vol. 87, No. 2, pp. 333-338. Only correlation is considered to test the hypotheses.

Paper 3: Edward L. Glaeser; David I. Laibson; Jose A. Scheinkman; Christine L. Soutter (2000), Measuring Trust, The Quarterly Journal of Economics, Vol. 115, No. 3, pp. 811-846. Probit and OLS regressions are used in the analysis. See Table 2, pp. 817.

Paper 4: Guiso, Luigi, Paola Sapienza and Luigi Zingales (2003), People's Opium? Religion and Economic Attitudes, Journal of Monetary Economics, Vol. 50, No. 1, pp. 225-82. There are total 52,252-95,739 observations; but for demographic characteristics and religion factors, they are regressed in two different models, see Table 2 (page 243) for demographic characteristics regression; Table 4 on page 256 for religion regression.

Paper 5: Guiso, Luigi, Paola Sapienza and Luigi Zingales (2006), Does Culture Affect Economic Outcomes? Journal of Economic Perspectives, Vol. 20, No. 2, pp. 23-48. The analysis is controlled by health, male, age, education, social class, income. But coefficients are not reported, see Figure 1 , page 30 of working paper

Paper 6: Knack, S., and P. Keefer (1997), Does Social Capital Have an Economy Payoff ? A Cross-Country Investigation, Quarterly Journal of Economics, Vol. 112, No. 4, pp. 1251-1288. The study used OLS regression based on aggregated data from WVS data source. There are total 29 countries. Table 6 and 7 , on page 1280 and 1281 use trust as dependent variable; Table 5 uses trust as independent variable. 
Paper 7: Zak, Paul J and Stephen Knack (2001), Trust and Growth, The Economic Journal, 111 (April), p. 295-321. This study aggregated WVS data to 41 countries and used OLS analysis. The results are displayed in Table 1 and Table 2 in the paper.

Paper 8: Beugelsdijk, S. and T. von Schaik (2001), “Social Capital and Regional Economic Growth”, CentER Discussion Paper, December. Religion is not considered in this paper. The authors aggregated WVS data to 54 regions in 7 European countries and did OLS analysis, Trust was treated as independent variable.

Paper 9: Berggren, N., H. Jordahl (2006), Free to Trust: Economic Freedom and Social Capital, Kyklos, Vol. 59, No. 2, pp. 141-169. This paper used IV method to test causal relationship between trust and economic freedom. Total 51or 52 countries are considered in the analysis. Results are in Table 2, p. 153

Paper 10: Uslaner, Eric M. (2004), Trust, Democracy, and Governance: Can Government Policies Influence Generalized Trust? in Dietlind Stolle and Marc Hooghe, eds., Generating Social Capital (Palgrave, 2004), http://www.bsos.umd.edu/gvpt/uslaner/generating5uslaner.doc. OLS regression and 33 countries are used in the analysis.

Paper 11: Tabellini, Guido (2005), Culture and institutions: economic development in the regions of Europe, working paper. OLS and 69 regions in 8 European countries are used and the result is in Table 10, p. 61 